\title{
The Central Contributions of Breast Cancer Stem Cells in Developing Resistance to Endocrine Therapy in Estrogen Receptor (ER)-Positive Breast Cancer
}

\author{
David Rodriguez ${ }^{1,2,3,4,+}{ }^{+}$, Marc Ramkairsingh 1,2,3,4, ${ }^{+}$, Xiaozeng Lin 1,2,3,4 Anil Kapoor $2,3,5$, \\ Pierre Major ${ }^{6}$ and Damu Tang ${ }^{1,2,3,4, *}$ \\ 1 Department of Medicine, McMaster University, Hamilton, ON L8S 4K1, Canada \\ 2 The Research Institute of St Joe's Hamilton, St Joseph's Hospital, Hamilton, ON L8N 4A6, Canada \\ 3 Urological Cancer Center for Research and Innovation (UCCRI), St Joseph's Hospital, \\ Hamilton, ON L8N 4A6, Canada \\ 4 The Hamilton Center for Kidney Research, St. Joseph's Hospital, Hamilton, ON L8N 4A6, Canada \\ 5 Department of Surgery, McMaster University, Hamilton, Hamilton, ON L8S 4K1, Canada \\ 6 Division of Medical Oncology, Department of Oncology, McMaster University, \\ Hamilton, ON, L8V 5C2, Canada \\ * Correspondence: damut@mcmaster.ca; Tel.: +1-(905)-522-1155 (ext. 35168); Fax: +1-(905)-521-6181 \\ + Equal contributions.
}

Received: 22 June 2019; Accepted: 17 July 2019; Published: 22 July 2019

\begin{abstract}
Breast cancer stem cells (BCSC) play critical roles in the acquisition of resistance to endocrine therapy in estrogen receptor (ER)-positive (ER + ve) breast cancer (BC). The resistance results from complex alterations involving ER, growth factor receptors, NOTCH, Wnt/ $\beta$-catenin, hedgehog, $\mathrm{YAP} / \mathrm{TAZ}$, and the tumor microenvironment. These mechanisms are likely converged on regulating BCSCs, which then drive the development of endocrine therapy resistance. In this regard, hormone therapies enrich BCSCs in ER + ve BCs under both pre-clinical and clinical settings along with upregulation of the core components of "stemness" transcriptional factors including SOX2, NANOG, and OCT4. SOX2 initiates a set of reactions involving SOX9, Wnt, FXY3D, and Src tyrosine kinase; these reactions stimulate BCSCs and contribute to endocrine resistance. The central contributions of BCSCs to endocrine resistance regulated by complex mechanisms offer a unified strategy to counter the resistance. ER + ve BCs constitute approximately $75 \%$ of BCs to which hormone therapy is the major therapeutic approach. Likewise, resistance to endocrine therapy remains the major challenge in the management of patients with $\mathrm{ER}+\mathrm{ve} \mathrm{BC}$. In this review we will discuss evidence supporting a central role of BCSCs in developing endocrine resistance and outline the strategy of targeting BCSCs to reduce hormone therapy resistance.
\end{abstract}

Keywords: ER-positive breast cancer; endocrine therapy resistance; breast cancer stem cells; hormone and growth factor signaling; microenvironment

\section{Introduction}

Approximately 1.7 million women are diagnosed with breast cancer $(\mathrm{BC})$ every year; the disease causes half a million deaths annually worldwide [1,2]. BC is a heterogeneous disease; it consists of tumors expressing estrogen receptor (ER) and/or HER2, as well as tumors negative for ER, progesterone receptor (PR), and HER2 expression (triple negative/TN), with approximately $75 \%$ of cases being ER-positive (ER + ve) [3-5]. This is consistent with an essential role of ER in breast development; in humans, ER expression was detected in breast epithelial cells from 30 weeks gestation and onward [6]; in mice deficient of ER, the rudimentary ductal structures of early gestation were unable to develop [7]. 
Likewise, ER signaling contributes to BC tumorigenesis and progression; ER transactivates hundreds of genes promoting BC growth [8], including Myc, cyclin D1, BCL-2, and vascular endothelial growth factor (VEGF) [9-12].

The functionality of ER in breast cancer highlights hormone therapy as the major treatment for ER + ve BCs. The therapy started following the introduction of tamoxifen, a selective estrogen receptor modulator (SERM), in the 1970s [13]. Since then, the selective estrogen receptor degrader (SERD) fulvestrant [14,15] and a set of aromatase inhibitors (AIs) have been developed [16]. AIs are the standard of care in adjuvant-based endocrine therapy in postmenopausal patients [17], while tamoxifen is preferred as adjuvant hormone therapy in the premenopausal setting [13]. Fulvestrant can be used either as first-line hormone therapy or following failure of tamoxifen and AI treatments $[18,19]$. Endocrine therapy to ER + ve BCs is among the most effective targeted cancer therapies. In first-line tamoxifen treatment, $67 \%$ of patients show responses [18,20,21]; adjuvant tamoxifen reduces the annual rate of mortality and recurrence by $31 \%$ and $50 \%$ respectively $[22,23]$. The hormonal agents of tamoxifen, fulvestrant, and AIs offer palliation benefits in treating ER + ve metastatic BCs and a long-term delay of disease recurrence under adjuvant setting.

However, endocrine therapy resistance (ETR) occurs. The resistance can be either intrinsic (de novo) or acquired; over $30 \%$ of ER + ve BCs display intrinsic ETR [24]. Approximately $30 \%$ of patients develop resistance to adjuvant tamoxifen $[23,25]$ and endocrine therapy in general $[23,26]$. These resistant tumors can remain dormant and are trigged for metastasis up to 20 years following diagnosis $[27,28]$. For advanced BCs, ETR can be rapidly developed; these tumors are defined as relapse arisen within two years of endocrine therapy or one year after completion of adjuvant hormone therapy according to the recent ESO-ESMO (European School of Oncology-European Society for Medical Oncology) guidelines [29,30]. Relapse of ER + ve BCs to hormone therapy is regulated by a complex network, which includes modulations of ER signaling, activation of epidermal growth factor receptor (EGFR) and other growth factor receptors, $\mathrm{NOTCH}$, microenvironmental cues, and others. However, this rich knowledge at the molecular level has yet to translate into the clinic to counter ETR; the resistance remains a major cause of breast cancer fatality.

At the cellular level, relapse on endocrine therapy requires tumor regrowth, a process that shares similarities with the expansion and regeneration of mammary glands in reproductive cycles of females, in which mammary stem cells (MaSCs) are responsible for the regeneration. Likewise, breast cancer stem cells (BCSCs) mediate the recurrence to endocrine therapy, which is in line with the consensus that cancer stem cells (CSCs) are the driving force of cancer evolution and resistance to therapies [31]. In this regard, the aforementioned molecular mechanisms would be converging on regulating BCSCs and thereby lead to ETR. In this review we will briefly introduce BCSC, review evidence supporting BCSC being a cause of ETR, discuss a strategy to reduce ETR by targeting BCSCs, propose a model of $\mathrm{BCSC}$ regulation, and address limitations.

The main materials reviewed in this manuscript were selected according to the PRISMA Guidelines $[32,33]$. We performed a systemic literature search through the PubMed database using the term: "breast cancer AND endocrine therapy resistance AND breast cancer stem cells". A total of 94 articles were retrieved; among these, non-English articles $(n=3)$ and not-directly relevant publications $(n=28)$ were removed (Figure 1). 


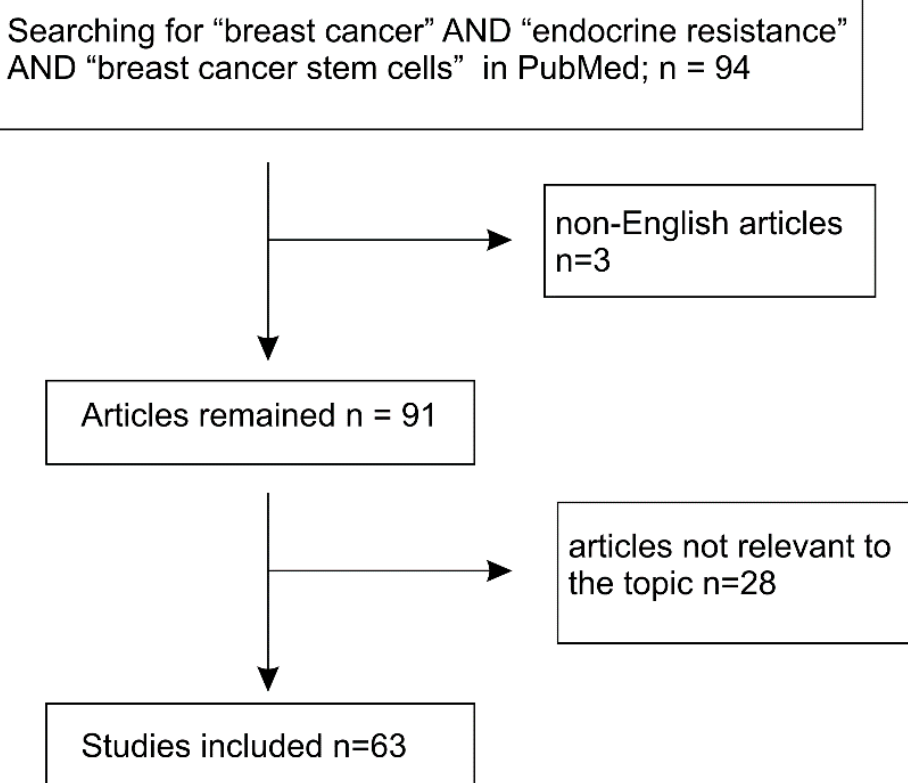

Figure 1. Systemic literature searching conditions and selection of articles for review.

\section{Breast Cancer Stem Cells}

CSCs were first demonstrated in acute myeloid leukemia (AML) as the tumor cells bearing the surface profile of CD $34^{+} \mathrm{CD} 38^{-}$in 1994 [34]. In solid tumors, BCSCs with the profile of CD44 ${ }^{+} \mathrm{CD} 24^{-/ 10 w}$ were initially isolated from patients by Al-Hajj et al. in 2003 [35], which ignited enthusiasm in CSC research in solid tumors due to immediate recognition of the central potential of CSCs in cancer initiation, progression, and resistance to therapies. This intensive research has led to the identification of CSCs in almost all types of solid tumors [36,37], including bladder cancer [38], brain tumors [39], colon cancer [40,41], head and neck squamous cell carcinoma [42], liver cancer, lung cancer [43], melanoma [44], pancreatic cancer [45,46], prostate cancer [47] and sarcoma [48]. The initial identification was largely attributed to the assumption of sharing surface biomarkers between CSCs and their counterparts of tissue stem cells (SCs) [49].

The dramatic ability of undergoing cycles of growth and involution throughout the female reproductive life clearly demonstrates the existence of MaSC in the mammary gland epithelial compartment [50]. MaSCs have been demonstrated by the transplantation (mammary gland reconstitution) approach [51,52] and lineage-tracking experiments [53-55]. Nonetheless, the identity of MaSCs remains unclear; a variety of marker profiles have been reported in these cells, including $\mathrm{Lin}^{-} \mathrm{CD} 29^{\mathrm{hi}} \mathrm{CD} 24^{+}$( $\mathrm{Lin}^{-}$: lineage negative) [56], Lgr5 ${ }^{+}$Tspan8 ${ }^{\mathrm{hi}}$ [57], Bcl11b ${ }^{+}$[58],

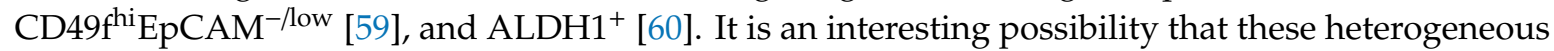
cells, with the ability to reconstitute mammary glands, may represent the breast epithelial hierarchy. For example, quiescent MaSCs replenish proliferative MaSCs, which then generate mammary glands [61]. This similar strategy has been well documented in intestinal epithelial stem cell populations, the quiescent $\mathrm{BMI}^{+}$stem cells and proliferative $\mathrm{Lgr}^{+}$stem cells [62]. Intriguingly, BCSCs are also heterogeneous with respect to marker expression. Following the initial identification of BCSCs as $\mathrm{CD}_{4}{ }^{+} \mathrm{CD} 24^{-/ \text {low }} \mathrm{ESA}^{+} \mathrm{Lin}^{-}$(ESA: epithelial specific antigen) [35], ALDH1 ${ }^{+}$[60], CD49f ${ }^{+}$[63], and $\mathrm{CD}_{133^{+}}[64]$ have also been reported to mark BCSCs. The CD133 ${ }^{+}$BCSCs are enriched in TN breast cancers [65], while the CD49f ${ }^{+}$BCSCs were correlated with resistance to chemotherapy in TN breast cancers [63]. Both $\mathrm{CD} 44^{+} \mathrm{CD} 24^{-/ \mathrm{low}}$ and $\mathrm{ALDH} 1^{+}$BCSC populations were associated with adverse features in luminal (ER+ve) BCs, including Ki67 as well as basal markers: p63, CK5/6, and CK14 (CK: cytokeratin) [66] and with poor prognosis [67]; $\mathrm{ALDH}^{+} \mathrm{BCSC}$ are particularly correlated with early recurrence following endocrine therapy [68]. These observations support a positive contribution 
of BCSCs in the development of resistance to endocrine therapy. However, there are differences in the association of these two BCSC populations with features favoring endocrine resistance in luminal $\mathrm{BC}$; the $\mathrm{CD} 44^{+} \mathrm{CD} 24^{-/ \text {low }}$ but not the $\mathrm{ALDH} 1^{+} \mathrm{BCSC}$ population was correlated with the HER2 status [66]. The heterogeneous status of BCSCs suggests that individual BCSC populations make unique contributions to ETR in a context-dependent manner. This possibility is supported by the reverse association of the $\mathrm{ALDH} 1^{+}$instead of $\mathrm{CD} 44^{+} \mathrm{CD} 24^{-/ \mathrm{low}} \mathrm{BCSC}$ population with a response to neoadjuvant chemotherapy [69]. The potential contributions of $\mathrm{CD} 44^{+} \mathrm{CD} 24^{-/ \text {low }}$ and $\mathrm{ALDH} 1^{+} \mathrm{BCSCs}$ in ETR acquisition will be discussed later.

\section{Association of Endocrine Therapy Resistance with BCSC Enrichment}

Consistent with the CSC model for a central role of CSCs in developing resistance to therapies, cumulative evidence reveals an enrichment of BCSCs in ETR. In vitro, the tamoxifen-resistant derivatives of MCF7 cells (MCF7-TamR) were enriched with BCSCs. The rate of CD44 ${ }^{+} \mathrm{CD} 24^{-/ \text {low }}$ cells in MCF7-TamR was increased [70,71]; elevations in ALDH activity, indicative of an increase in ALDH1 [72], and CD133 [73] were reported in MCF7-TamR compared to MCF7 cells. Treatment with tamoxifen for five days increased the mammosphere forming ability of MCF7 and LM05-E cells (estrogen-dependent murine BC cells) [74]. In vivo, tamoxifen treatment elevated the CD29hi CD24 ${ }^{\text {low }}$ BCSC population [74]. In patients treated with the AI letrozole, an enrichment in CD44 ${ }^{+} \mathrm{CD} 24^{-/ l o w}$ BCSCs was observed [75]. Both mammosphere and xenograft tumors derived from patients treated with either tamoxifen or fulvestrant showed increases in ALDH1 ${ }^{+}$BCSCs (Table 1) [76].

Collectively, accumulating evidence obtained from in vitro examination, in vivo research, and clinical samples clearly demonstrates elevations of BCSCs in tumors with acquired resistance to endocrine therapy (Table 1). Intriguingly, the enrichment can be achieved at a very early stage of endocrine treatment. For instance, in vitro treatment with tamoxifen or fulvestrant for five to nine days and in vivo treatment with both agents for 14 days significantly increased the BCSC content $[74,76]$ (Table 1), while prolonged treatment, approximately one-year in vitro and four to five weeks in vivo with tamoxifen, is required to reach a stable status of resistance [77]. These observations thus suggest a causal relationship between BCSC enrichment and the acquisition of ETR.

The BCSCs are enriched in different populations (Table 1). An interesting question is whether these individual populations are largely the same or equivalent. Limited evidence suggests that they are related but not identical. In MCF7 cells, the CD44 ${ }^{\text {hi }} \mathrm{CD} 24^{-/ \mathrm{low}}$ and $\mathrm{ALDH} 1^{+}$BCSCs were $12.87 \%$ and $5.54 \%$ respectively with an overlap of $0.084 \%$ (Figure 2A) [78]; similar observations were also obtained in MCF10A cells with different percentages [78]. While the CD44hi CD24-/low BCSCs display an epithelial-mesenchymal transition (EMT) status, the ALDH1 ${ }^{+}$BCSCs possessed a mesenchymal-epithelial transition (MET) state (Figure 2A) [78]. In a tumor mass, the CD44hi $\mathrm{CD} 24^{-/ \text {low }}$ BCSCs and the ALDH1 ${ }^{+}$BCSCs are respectively quiescent and proliferative (Figure 2A) [78]. In breast, quiescent MaSCs progress to proliferative MaSCs which then produce mammary glands (Figure 2B) [61]. With this knowledge, it can envisage a model in which CD44 ${ }^{\text {hi }} \mathrm{CD} 24^{- \text {low }}$ BCSCs are converted to $\mathrm{ALDH}^{+}{ }^{+} \mathrm{BCSC}$ s and the latter BCSCs directly produce relapsed tumors (Figure 2A). This model can be readily tested. In fact, had the studies (Table 1) examined both populations of BCSCs with respect to their time-wise enrichment, their contributions and relationship to ETR development could be evaluated. Nonetheless, the model (Figure 2A) predicts the generation of ALDH1 ${ }^{+}$BCSCs will be a later event following the early production of CD $44^{\text {hi }} \mathrm{CD} 24^{- \text {low }}$ BCSCs in the process of endocrine treatment. This scenario is supported by the inhibition of cell proliferation by tamoxifen and fulvestrant in a short term treatment with the concurrent appearance of CD44 ${ }^{\text {hi }} \mathrm{CD} 24^{-/ \text {low }}$ BCSCs [76]; while $\mathrm{CD} 44^{\text {hi }} \mathrm{CD} 24^{-/ \text {low }}$ BCSCs are quiescent, $\mathrm{ALDH} 1^{+}$BCSCs are proliferative (Figure 2A) [78]. 
Table 1. Enrichment of BCSC following endocrine treatment.

\begin{tabular}{|c|c|c|c|}
\hline Treatment & System $^{1}$ & BCSC $^{2}$ & Ref. \\
\hline Tamoxifen & MCF7-TamR & $\mathrm{CD} 44^{+} \mathrm{CD} 24^{-/ \text {low }}$ & [70] \\
\hline Tamoxifen & MCF7-TamR & $\begin{array}{l}\mathrm{CD} 44^{+} \mathrm{CD} 24^{-/ \text {low }} \\
\text { Mammosphere }\end{array}$ & [71] \\
\hline Tamoxifen & MCF7-TamR & $\mathrm{ALDH}^{+}$ & [72] \\
\hline Tamoxifen & MCF7-TamR & $\begin{array}{c}\text { CD133+ } \\
\text { Mammosphere }\end{array}$ & [73] \\
\hline Tamoxifen & MCF7 and LM05-E, 5 days treatment & Mammosphere & [74] \\
\hline Tamoxifen & MCF7-TamR & $\mathrm{CD} 44^{+} \mathrm{CD} 24^{-/ \text {low }}$ & [74] \\
\hline Tamoxifen & LM05-E xenografts ${ }^{3}$ & CD29hi CD24 $4^{\text {low }}$ & [74] \\
\hline Letrozole & Patient BCs & $\mathrm{CD} 44^{+} \mathrm{CD} 24^{-/ \mathrm{low}}$ & [75] \\
\hline $\begin{array}{l}\text { Tamoxifen }^{4} \\
\text { Fulvestrant }\end{array}$ & $\begin{array}{l}\text { Patient-derived mammosphere, } 7-9 \text { days } \\
\text { Patient-derived xenograft, } 14 \text { days }\end{array}$ & $\mathrm{ALDH}^{+}$ & [76] \\
\hline
\end{tabular}

1 systems and conditions used to derive endocrine resistance; ${ }^{2}$ BCSC populations; ${ }^{3}$ murine tumor; ${ }^{4}$ both cells isolated from patients samples or patient-derived xenografts were treated individually with tamoxifen and fulvestrant.

A

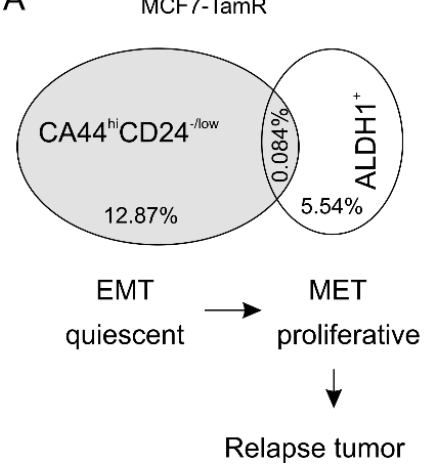

B

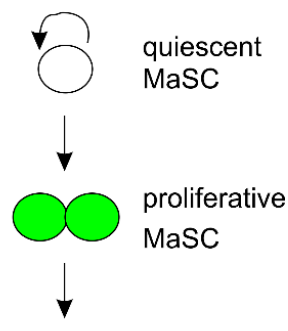

mammary glands

Figure 2. A model shows different contributions of individual BCSC populations in endocrine resistant development. (A) The percentage of the indicated BCSC pools in MCF7-TamR cells and their relationship are shown. EMT: epithelial-mesenchymal transition; MET: mesenchymal-epithelial transition. (B) Evidence supports that quiescent MaSCs are self-renewal and produce proliferative MaSCs; the latter cells generate mammary glands containing basal and luminal epithelial cells.

\section{Mechanisms Underlying BCSC Enrichment Following the Development of Endocrine Resistance}

Endocrine resistance is regulated by complex mechanisms, including ER, growth factor receptors/PI3K-AKT-mTOR, NOTCH, Wnt, Hippo-YAP/TAZ, and microenvironment cues (Figure 3). We will discuss the impact of these mechanisms on BCSC enrichment in ETR.

A

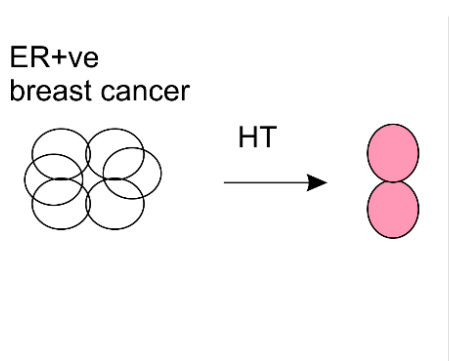

B

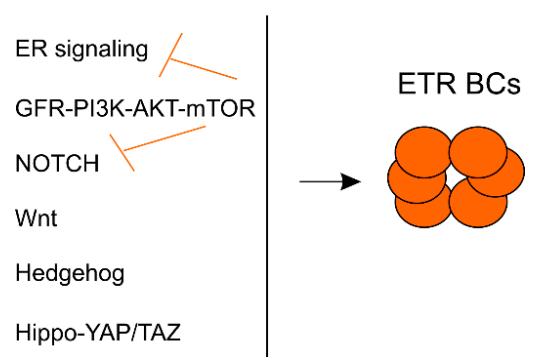

Figure 3. Mechanisms responsible for ETR (endocrine therapy resistance) progression. ER+ve breast cancers are treated with hormone therapy (HT) (A). (B) The treatment results in surviving cells harboring elevations in ER signaling, growth factor receptor (GFR)-PI3K-AKT-mTOR, NOTCH, or other pathways. The GFR-PI3K-AKT-mTOR pathway inhibits the ER and NOTCH signaling. (C) These pathways (B) drive the progression of tumors with resistance to endocrine therapy (ETR). 


\subsection{The Relationship of ER Signaling and BCSCs in Resistance to Endocrine Therapy}

Luminal BCs are largely ER + ve tumors; based on the guidelines of the American Society of Clinical Oncology/College of American Pathologists (ASCO/CAP), luminal BCs are tumors with $\geq 1 \%$ of ER + ve or PR + ve cells [79], indicating the importance of ER in predicting the response to hormone therapy. The primary mechanism for intrinsic resistance to endocrine therapy is a lack of ER expression [23]. In the setting of acquired ETR, loss of ER occurred in 17-28\% of relapse tumors [80-82] and the ER + status is largely maintained in resistant tumors $[81,83,84]$. In patient-derived xenograft (PDX, ER + ve) tumors, tamoxifen treatment and estrogen removal, which mimics AI treatment, increased ER content [85], which supports contributions of ER signaling to endocrine resistance. The ER in relapse BCs is functional, as a large proportion of these tumors are sensitive to alternative endocrine treatment. For example, nearly $20 \%$ of relapse BCs resistant to tamoxifen respond to second-line endocrine treatment with AIs or fulvestrant $[86,87]$. Recent evidence favors that ER (ER $\alpha)$ signaling is a major mechanism underlying endocrine resistance $[88,89]$. Sustaining of ER function can be mediated by modulations of either the ER or its transcriptional co-factors.

\subsubsection{Alterations of ER in Relapse Tumors Treated with ENDOCRINE Therapy}

Amplification of the ER $\alpha$ encoding gene ESR1 occurs in preclinical settings involving tamoxifen and fulvestrant [90] and in clinical BCs progressed in endocrine therapy with varied frequency [91-96]. The amplification was enriched in bone metastases [97] and could be associated with poor prognosis in patients with ER + ve BCs following adjuvant tamoxifen therapy [95]. ESR1 amplification was observed in relapse tumors progressed on either AI (24\%) or tamoxifen (13\%) [98]. Additionally, in both discovery and validation cohorts, CYP19A1 (encoding aromatase) amplification was detected in $16 \%$ and $32 \%$ of AI-treated patients respectively as well as in 3\% and 5\% of patients treated with tamoxifen [98]. CYP19A1 amplification promotes ER signaling through estrogen autocrine [98]. In support of this autocrine-mediated ER activation, AI treatment enhances cellular cholesterol biosynthesis, thereby upregulating estrogen autocrine [99].

Accumulating evidence as reviewed by Pejerrey et al. [100] clearly underpins a major contribution of recurrent ESR1 mutations, particularly in the hormone binding domain (HDB), in developing ETR and specifically in metastases that resulted from these resistant tumors. Ligand-independent ER activation occurred through missense mutations in the ESR1 gene, including Y537S, Y537N, and D598G [101-105]; these mutations arose in relapse tumors following endocrine therapy and their expression conferred resistance to tamoxifen [103-105]. They were detected in nearly $20-30 \%$ of relapse BCs [103-107], indicating a major role of these mutations in the development of endocrine resistance. This concept is in accordance with the repeated discovery of these mutants and E380Q in numerous studies (see Review by Pejerrey et al. [100] for details); mutations in ESR1 arise in $20-40 \%$ of metastatic BCs treated with endocrine therapy [100]. Functionally, ectopic expression of the Y537S mutant in MCF7 cells enriched CD44 ${ }^{+} \mathrm{CD} 24^{-}$cells, increased cell's mammosphere formation capacity, and upregulated stemness genes including OCT4, SOX2, SOX9, BMI1 and others along with an enrichment in NOTCH signaling [108]. The enhancement of BCSCs required ER signaling, as evident by an increase in the phosphorylation of ER $\alpha$ at serine 118 (pS118) and inhibition of this event abolishing BCSC enrichment [108]; pS118 is well characterized to increase ER transcription activity and is induced by tamoxifen [109]. ER $\alpha-Y 537 S$ was also incapable of enhancing BCSCs upon inhibition of NOTCH signaling, demonstrating that the interplay between ER and NOTCH plays a critical role in ER $\alpha$-Y537S-mediated BCSC enrichment [108]. Overexpression of either the ESR1-Y537N or ESR1-D598G mutant in MCF7 also induced pS118 along with an upregulation of mammosphere formation [108]. Collectively, evidence supports that ESR1 mutations in HDB, at least for Y537S, Y537N and D598G contribute to endocrine resistance at least in part via BCSC enrichment.

Besides the above missense mutations, a set of ESR1 fusion genes were detected in endocrine resistant tumors. The ESR1 gene consists of 10 exons consisting of (1) two non-coding exons, (2) exons 3-6 encoding an activating motif, DNA binding domain, and a hinge region, and (3) the remaining 
exons coding for an LBD (ligand-binding domain) (Figure 4). The first two exons of ESR1 were found to fuse with an N-terminal truncated CCDC170 fragment ( $\triangle C C D C 170)$ (Figure 4) [110]; the fusion gene was enriched in endocrine resistant luminal $\mathrm{B}$ breast cancers and its expression was driven by the ESR1 promoter [110]. Ectopic expression of $\triangle C C D C 170$ conferred resistance of T47D cells to tamoxifen in vitro and in vivo (xenografts) [110]. Similar fusion with C6orf211 was also identified in tumors resistant to AI (Figure 4) [111]. Additionally, recurrent fusion genes are more commonly involved in the N-terminal ESR1 at breakpoints between exons 6 and 7 to C-terminal partners (Figure 4 . The EST1 portion in these fusion genes lacks the LBD (Figure 4); the fusion proteins thus bind ER targets independent of the ligand estrogen. The fusion partners include in-frame C-terminal YAP, PCDH11X [112,113], DAB2 (disabled homolog 2), GYG1 (glycogenin 1), SOX9, MTHFD1L, PLEKHG1, TFG, NKAIN2, AKAP12, and CDK13 (Figure 4) [114]. The fusion proteins of ESR1-YAP1, ESR1-PCDH11X, ESR1-DAB2, ESR1-GYG1, and ESR1-SOX9 substantially increase ER transcriptional activity, independent of ligand association, and confer anti-hormone actions [112-114]. While the contributions of these ESR1 function genes in BCSC acquisition during ETR remain to be directly demonstrated, ectopic expression of either ESR1-YAP1 or ESR1-PCDH11X in T47D cells conferred resistance to fulvestrant with concurrent enrichment in the ER and EMT processes [113]. EMT plays a fundamental role in CSC [115]. Evidence thus suggests these fusion genes contribute to endocrine resistance in part through BCSC enhancement.

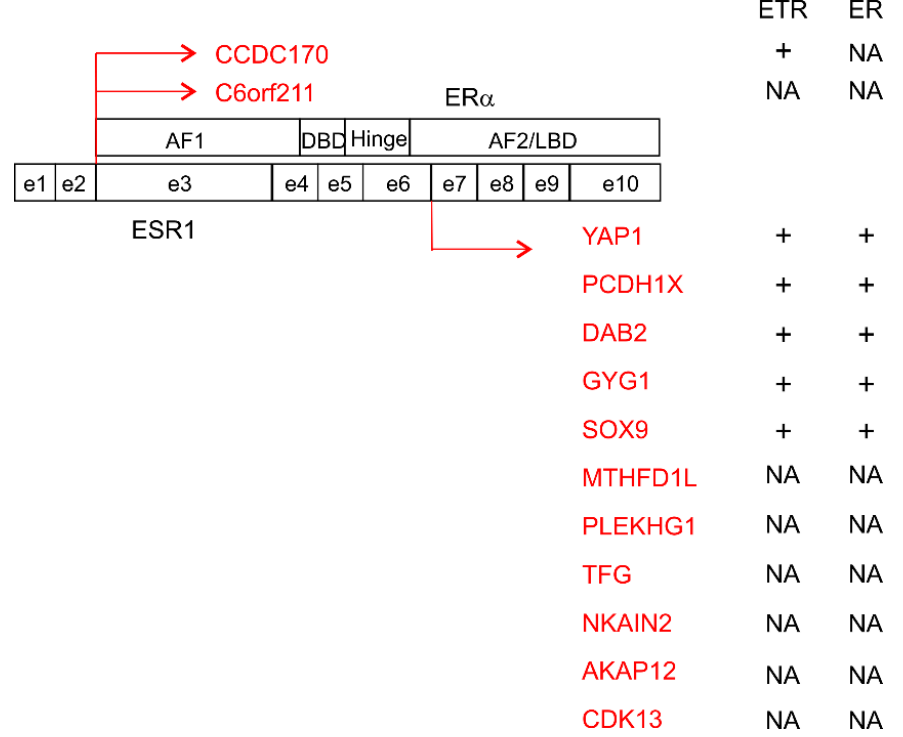

Figure 4. ESR1 fusion genes detected in patients with ETR breast cancers. The exons (e1-e10) of the ESR1 gene and the domain structure of ER $\alpha$ are shown. The fusion of $\mathrm{e} 2$ and e 6 to the indicated partners and the impact of individual fusion products on ETR and ER transcriptional activity are provided. AF1: activation function 1 domain; DBD: DNA-binding domain; Hinge: hinge region; AF2/LDB: activation function 2/ligand-binding domain; +: enhancement; NA: not available.

\subsubsection{Elevation in ER Signaling via Its Co-Transcriptional Factors in Endocrine Resistance}

The association of ER with chromatin requires its pioneer factors, including FOXA1 $[8,116,117]$, PBX1, and others $[118,119]$. Amplification of the PBX1 gene in ER + ve tumors was associated with metastasis and poor prognosis. PBX1 facilitates ER signaling [120], was suggested to control $70 \%$ of ER response, is required for ER-mediated proliferation of MCF7 cells, and can stratify the metastatic risk of $\mathrm{ER}+\mathrm{ve} \mathrm{BC}$ [121]. Evidence thus supports an important role of PBX1 in developing endocrine resistance.

In a study of $1501 \mathrm{ER}+$ ve BCs including 692 tumors treated with hormone therapy, genomic alterations in ER transcriptional regulators including FOXA1 were enriched in the treated tumors [122]. FOXA1 was reported to program ER binding to genes functioning in ETR development and 
BC metastasis [123]. Some targets were AGR2 and IL-8; FOXA1 mediated AGR2 expression in tamoxifen-resistant ER + ve BC cells [124] and promoted resistance to tamoxifen in part through IL-8 functions, as knockdown of IL-8 attenuated the resistance [125].

Besides the pioneer factor to recruit ER to chromatin, Mediator Subunit 1 (MED1) brings a mediator complex to the ER via direct association with the ER, thereby playing an important role in ER-derived target gene expression [126,127]. Consistent with HER2 promoting the endocrine resistance of ER + ve BCs, MED1 expression was correlated with HER2 expression and facilitated the communication between ER and HER2, which contributed to HER2-derived promotion of endocrine resistance; downregulation of MED1 reduced the resistance [128-130]. Collectively, evidence supports that through mediating ER target gene expression, the pioneer factors and co-regulators of ER play roles in endocrine resistance.

ER transcriptional activity is regulated by its co-activators with AIB1 (the ER modulator Amplified in Breast Cancer-1) being notably involved in endocrine resistance. AIB1 amplification and its upregulation in expression were detected in $10 \%$ and more than $50 \%$ of primary BCs respectively [131]. AIB1 upregulation is associated with HER2 expression and resistance to tamoxifen in primary BCs [132]. AIB1 binds to the ER in response to tamoxifen, which enables the ER to transactivate HER2 [132]; AIB1 thus plays a direct role in bridging the communication of ER with the HER2 growth factor receptor; the communication contributes to BCSC enrichment in endocrine resistance (see Section 4.2). Additionally, AIB1 sustains embryonic stem cells through facilitation of OCT4, NANOG, and SOX2 expression [133], and promotes CSC formation [134]. In ER + ve BCs, AIB1 contributes to the formation of ALDH+ mammospheres [135]. Collectively, evidence supports a role of the ER co-activator AIB1/NCOA3/SRC3 (steroid co-activator 3) in ETR via BCSC enrichment.

\subsubsection{The Impact of ER Signaling on Endocrine Resistance-Associated Enrichment of BCSCs}

Relapse of ER + ve BCs on endocrine therapy results in tumor regrowth and evolution; both processes are attributable to BCSC's capacities of tumor initiation and plasticity. Likewise, ER signaling sustained under hormone therapy will be expected to enrich BCSCs. There is indirect evidence supporting this concept. MaSCs are ER-ve and ER signaling reduces the pool of MaSCs $[61,136]$. Whilst the ER status of BCSCs enriched in ER + ve tumor cells resistant to endocrine therapy is not clear, evidence suggests the ER-ve status of both CD44 ${ }^{+}$CD24-/low and ALDH1 ${ }^{+}$BCSCs $[76,137,138]$. This concept is in accordance with the observations that endocrine treatment with either tamoxifen or fulvestrant reduced the proliferation of ER + ve cells with a concurrent increase of BCSCs [76] and that knockdown of FOXA1 attenuated MCF7 cell proliferation without impact on mammosphere formation [139]. Furthermore, Nasr et al. have recently established a BC cell line from a ER+/PR+/HER2tumor; the cell line consists of $92 \% \mathrm{ALDH}^{+}$cells and $0.97-5.4 \%$ of $\mathrm{CD} 44^{+} \mathrm{CD} 24^{-/ \text {low }}$ cells, and OCT4, SOX2, and NANOG were overexpressed, suggesting the line being essentially cells with BCSC properties [140]. Intriguingly, treating these cells with either estrogen, progesterone, or their inhibitors for six months did not affect cell proliferation [140]; however, the ER status in the cell line prior to and after treatments has not been documented [140].

Nonetheless, evidence supports the involvement of ER $\alpha$ transcriptional activity in BCSC enrichment during ETR progression. A MED1 mutant deficient in binding ER not only reduced ER target gene expression but also decreased the cell's ability to form a mammosphere [141]. Tamoxifen-induced pS118 increases ER $\alpha$ transcriptional activity [109] and predicts resistance to tamoxifen [142]; additionally, $\mathrm{ER} \alpha \mathrm{pS} 118$ communicates with SOX2, a critical factor regulating BCSCs (see Section 5), in BCSC acquisition [143]. Furthermore, the recent demonstration of the alterations in ESR1 following endocrine treatment (see Section 4.1.1) and the direct contributions of the ESR1 mutants Y537S, Y537N and D598G to BCSC enrichment clearly support the critical roles of ER $\alpha$ transcriptional activity in BCSC enrichment during the course of ETR.

However, the involvement of ER in BCSCs is likely complex. Although MaSCs do not express $\mathrm{ER} \alpha$, they are $\mathrm{ER} \beta$-positive. $\mathrm{ER} \beta$ was reported to contribute to $\mathrm{BCSC}$ enrichment under endocrine 
therapy [144]. Treatment of MCF7 cells with 17- $\beta$-estradiol increased mammosphere formation with respect to the number and size of spheres along with a significant upregulation of ER $\alpha 36$ [145]; the isoform lacks both AF-1 and AF-2 transactivation domains and a part of LBD [146]. ER $\alpha 36$ was reported to enhance BCSCs, confer resistance to tamoxifen, and promote metastasis $[147,148]$. ER $\alpha 36$ is upregulated in BCSCs, maintains $\mathrm{CD} 44^{+} \mathrm{CD} 24^{-/ \text {low }}$ BCSCs likely via activating the AKT pathway, and contributes to resistance to antiestrogen treatment $[149,150]$. Evidence thus reveals contributions of signaling events leading to AKT activation in ETR-associated BCSC enrichment.

\subsection{Growth Factor Signaling Stimulating BCSC Enrichment in Developing ETR}

In both preclinical models of resistance to tamoxifen and AI (long-term adaptation to estrogen deprivation), activation of the EGFR, IGFR (insulin-like growth factor receptor), PI3K-AKT-MAPK, and mTOR pathways was the consistently observed theme [151-154]. The contributions of these pathways in endocrine resistance have been well reviewed [3,25,154-160]. In this section we will discuss their connections to BCSCs in the context of ETR development.

Evidence favors the direct relevance of these pathways in BCSCs. In a profiling effort of 500 $\mathrm{CD} 44^{+} \mathrm{CD} 24^{-/ \text {low }} \mathrm{BCSC}$ s isolated from primary tumors using next generation sequencing technology, upregulations of the PI3K pathway, EGFR, and other growth factors were demonstrated [161]. In these BCSCs, the Wnt and NOTCH pathways along with stemness genes LIF and THY1 were also enriched [161]. The CSC markers of CD44, CD133, and ALDH1A3 were overexpressed with concurrent downregulation of CD24 as expected [161]. Additionally, mutations leading to activation of the PI3K-AKT-mTOR pathway were detected in BCSCs isolated from patient tumors [162,163]; among 11 BCSC samples, eight (73\%) harbored gain-of-function mutations in the PI3K-AKT pathway [162]. Furthermore, activation of the PI3K-AKT-mTOR pathway occurs in BCSCs associated with tamoxifen-resistant tumors; mRNA expression profiling of mammospheres expanded from patients treated with and without tamoxifen demonstrated activation of the mTOR pathway [164]. Activation of the AKT-mTOR pathway can be achieved by overexpression of miR-125b or downregulation of miR-424; these alterations confer resistance to AI along with an increase of BCSCs [165]. Collectively, evidence, although not substantial, supports a direct role of the PI3K-AKT-mTOR pathway in promoting BCSCs in the course of endocrine resistance progression.

The functions of EGFR/HER2 in BCSCs are consistent with its specific involvement in MaSCs. EGFR/HER2 is expressed in MaSCs [166,167]. In a study of 577 BC patients, HER2 expression was positively correlated with ALDH1 ${ }^{+}$BCSCs [60]; enforced HER2 expression in BC cell lines increased ALDH1 ${ }^{+}$BCSCs, which was blocked by trastuzumab (Herceptin, a monoclonal anti-HER2 antibody) [168]. The axon guidance receptor UNC5A was recently shown to repress ER signaling and the CSC population in MCF7 and T47D cells; its knockdown enhanced both events along with increasing EGFR expression and AKT activities [169]. On the other hand, the retinoblastoma-binding protein 2 (RBP2) conferred tamoxifen resistance in part via activation of the IGF1R-HER2-PI3K-AKT pathway, as inhibition of PIK3 reduced the resistance [170]. Collectively, accumulating evidence clearly outlines an important role of the growth factor receptor (EGFR/HER2 and IGFR) in BCSC enrichment in the development of hormone resistance.

\subsection{NOTCH Pathway Regulating BCSCs in Endocrine Therapy}

The NOTCH signaling pathway plays a critical role in endocrine resistance through promoting BCSC enrichment [171]. The pathway is enriched in CD44 ${ }^{+} \mathrm{CD} 24^{-/ \text {low }} \mathrm{BCSC}$ s isolated from patients [161]. $\mathrm{NOTCH}$ is required to maintain multiple normal stem cells during development [172]. Its signaling plays a role in maintaining the bipotent progenitors of human mammary glands [173] and is required for the commitment of luminal epithelial cell fate of mouse mammary glands [174]. In the setting of tamoxifen-based hormone therapy, NOTCH4 was upregulated, conferred resistance to tamoxifen, and contributed to the stemness of tamoxifen-resistant MCF7 cells $[175,176]$. NOTCH4 induces resistance to endocrine therapy, either tamoxifen or fulvestrant-based, in part through sustaining BCSCs. The 
observed BCSC regulatory activity in these settings was mediated through the association of JAG1 (a NOTCH ligand) with NOTCH4 [76]. In the clinic, a signature of NOTCH4 with its downstream targets HES and HEY predicts poor response and poor prognosis in two-independent ER + ve BC cohorts; in vivo, the acquired tamoxifen-resistance of PDX is reversed along with reductions of BCSCS when NOTCH4 function was inhibited [76]. In line with these observations, NOTCH4 expression correlated with Ki67 expression (cell proliferation) in clinical samples and its inhibition using $\gamma$-secretase inhibitor sensitized TD47 cell-derived xenografts to tamoxifen [177]. Additionally, FKBPL (FK506-binding protein like) was very recently reported to reduce ETR via inhibiting the resistance-derived BCSCs; this inhibition was mediated by downregulation of NOTCH4 and its ligand DLL4 [178]. NOTCH actions may also be involved in a transition from more luminal A type tumors to luminal B BCs; the latter is associated with intrinsic resistance to endocrine therapy [179]. This provides additional support for an important role of NOTCH in developing resistance to hormone therapy. Collectively, these studies provide an elegant and convincing demonstration for a critical role of the NOTCH4 signaling in promoting BCSCs under endocrine treatment.

\subsection{The Wnt, Hedgehog, and Hippo-YAP/TAZ Pathways}

Wnt signaling plays essential roles in maintaining tissue stem cells $[180,181]$, cancer stem cells [182,183], and therapy-derived BCSCs [184]. Some key components of the Wnt pathway are upregulated in CD44 ${ }^{+} \mathrm{CD} 24^{-/ \text {low }}$ BCSCs isolated from patients [161]. In comparison to MCF7 cells, MCF7-TamR cells display resistance to tamoxifen with increases in Wnt signaling, proliferation activities, and EMT; all these are reversed following the addition of Wnt inhibitor IWP-2 [185]. SOX2 promotes resistance to tamoxifen through stimulating BCSCs, a process that is at least in part mediated by SOX2-induced Wnt signaling [71,186]. Wnt signaling works downstream of SOX9 in facilitating BCSCs, thereby promoting hormone resistance [187]; miR-190 sensitizes the response to anti-estrogen treatment by inhibiting Wnt signaling via downregulation of SOX9 [188].

The Hedgehog pathway is highly conserved, and plays essential roles during development and in the maintenance of tissue stem cells [189]. The pathway contributes to the self-renewal of CSCs [190] and its components are expressed in ER + ve BCs [191]; these components promote endocrine resistance [192]. The impact of the hedgehog pathway on $B C$ has been thoroughly reviewed recently [191]. While these studies support a role of Hedgehog in BCSC-mediated resistance to endocrine therapy, direct evidence and detailed mechanisms underlying the process are lacking.

The tumor suppression functions of the Hippo core kinases are mainly mediated by inhibition of the transcriptional coactivators YAP (Yes-associated protein 1) and TAZ (transcriptional coactivator with PDZ binding motif) [193]. Elevations in YAP/TAZ functions promote CSCs [194]. High levels of $\mathrm{YAP} / \mathrm{TAZ}$ expression are associated with reductions in metastasis-free survival in patients with breast cancer and adverse features of the disease [195]; TAZ is essential for sustaining the self-renewal of $\mathrm{CD} 44^{+} \mathrm{CD} 24^{-/ \text {low }}$ BCSCs [195]. It is intriguing that the fusion gene ESR1-YAP promotes resistance to endocrine therapy (Figure 4) [112]. The YAP/TAZ transcriptional coactivators cross-talk with the Wnt, Hedgehog, and NOTCH signaling pathways [196], which likely contributes to YAP/TAZ activities in maintaining the BCSC self-renewal potential. YAP/TAZ are able to sense stress and extracellular or microenvironmental signals to promote CSC evolution, thereby playing important roles in metastasis and resistance to therapies [193].

\subsection{Microenvironment Contributions to BCSC Evolvement Following Endocrine Resistance Development}

The microenvironment has a major impact on cancer evolution and the development of therapy resistance and it also influences the acquisition of endocrine resistance. In a murine estrogen-sensitive BC cell line (LM05-E), attachment to laminin upregulates the pluripotent genes SOX2, NANOG, and OCT4, increases mammosphere formation, and importantly induces resistance to tamoxifen through $\alpha 6$ integrin [197]. 
Extracellular vesicles (EVs) derived from cancer-associated fibroblasts (CAFs) induce endocrine resistance through regulating BCSCs. CAF-produced EVs from patients with hormone resistant metastatic BCs deliver mitochondrial DNA to the BCSCs of dormant hormone resistant BCs, which induces oxidative phosphorylation and subsequently "wakes up" the dormancy [198]. EVs derived from CAFs of patients with hormone resistant BCs can deliver miR-221, which enhances the generation of CD133 ${ }^{+}$BCSCs induced by endocrine therapy, thereby promoting ETR [199]. These processes are in part mediated by miR-221-initiated actions of the inflammatory cytokine IL6-STAT3 pathway [199].

Inflammation is a major contributor to hormone resistance [200,201], which is in part through stimulation of BCSCs. In this regard, gene expression profiling of MCF7-derived BCSCs shows an upregulation of inflammatory cytokines (like IL8) [202]. FOXA1 stimulates tamoxifen resistance in MCF7 cells in part through upregulation of IL8, as downregulation of IL8 abolishes the resistance [125]. In line with IL8, also known as CXCR8 (C-C-C motif ligand 8), functioning through CXCR1/2 [203], CXCR1/2 plays a key role in maintaining BCSCs [204-206]. The IL6-STAT3 pathway is activated after inactivation of the RB tumor suppressor and contributes to the self-renewal of BCSCs in the development of endocrine resistance [207]. The pathway maintains BCSCs in this setting in part via regulating the mitochondrial superoxide level [207]. IL33 was also reported to enhance BCSCs along with upregulations of SOX2, NANOG, and OCT4, and it promotes endocrine resistance [208].

\subsection{Other Factors-PAK4 Stimulating BCSCs in Response to Endocrine Treatment}

P21 activating kinase 4 (PAK4) belongs to the PAK family consisting of 6 PAK members functioning downstream of small Rho GTPases Rac and Cdc42 [209]. Elevation in PAK4 expression correlates with adverse characteristics of BC, including tumor size, lymph node involvement, and invasion [210-212]. High PAK4 expression stratifies the risk of tamoxifen resistance and poor prognosis of EV + ve BCs and is associated with poor outcome in patients treated with tamoxifen [213,214]. PAK4 expression is significantly upregulated in MCF7 cells resistant to either tamoxifen or fulvestrant along with BCSC enrichment; its knockdown reverses the resistance [214]. PAK4 promotes BCSCs under endocrine treatment in part via increasing ER transcriptional activity [213]. Collectively, evidence supports PAK4 promoting endocrine resistance at least in part via facilitating BCSCs.

\section{The Involvement of Core Stemness Genes in Regulating BCSCs during ETR Development}

A key contribution of BCSCs in acquired ETR can be further demonstrated by the contributions of core stemness genes of stem cells and CSCs, BMI1, NANOG, and SOX2. BMI1 is upregulated in $B C$ and associates with $B C$ progression and poor prognosis $[215,216]$. Its function in maintaining the self-renewal of tissue stem cells [62,217-220] and BCSCs (CSCs in general) $[221,222]$ has been well established. BMI1 confers resistance to tamoxifen in MCF7 and T47D cells in vitro; its overexpression coverts tamoxifen to an agonist to stimulate xenograft tumor growth in vivo [77].

Both NANOG and SOX2 are commonly upregulated in ER + ve BC cells in response to hormone treatment $[140,197,208]$. Knockdown of NANOG increased the sensitivity of MCF7-TamR cells to tamoxifen [223]. SOX2, a member of the SOX (SRY-related HMG-box) family [224], is a well-established factor required for the maintenance of embryonic stem cells, tissue stem cells and CSCs $[225,226]$. It plays a key role in BCSC enrichment in response to endocrine treatment through a pathway consisting of SOX2-SOX9-Wnt (Figure 5) [71,186,187]. Overexpression of SOX9 is sufficient to render resistance to hormone therapy [227]; its upregulation is via an RUNX2-ER complex, i.e., SOX9 is a target of ER in this setting [227]. Besides Wnt signaling, SOX9 induces FXY3D expression; the latter promotes SOX9 nuclear localization, forming a positive feedback loop (Figure 5) [228]. FXY3D is a member of the family of Na,K-ATPase regulators containing a FXYD domain [229]. FXY3D contributes to Src activation via forming a complex with ER and Src, which plays a role in endocrine resistance (Figure 5) [228]. Src tyrosine kinase activity enhances endocrine resistance [230] in part by regulating ER function via phosphorylation of ER [231]. Collectively, evidence reveals a pathway in which 
the SOX2-SOX9 axis stimulates Wnt or FXY3D-ER-Src actions to regulate BCSCs (Figure 5), thereby promoting endocrine resistance.

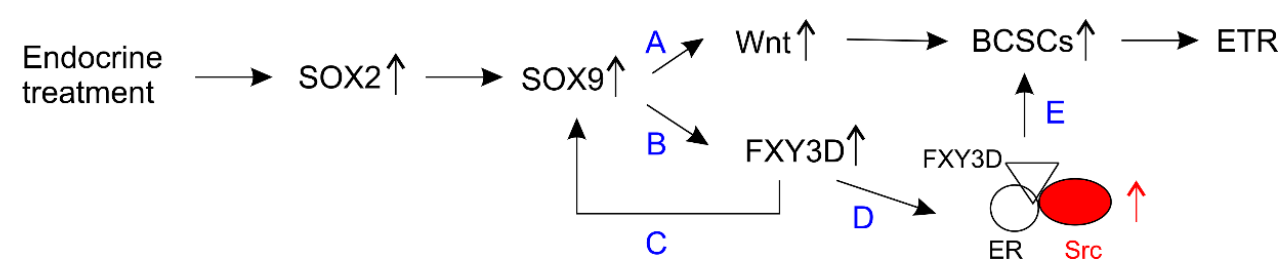

Figure 5. An illustration shows SOX2-initiated events in promoting ETR. Endocrine treatment leads to SOX2 upregulation indicated by the up-pointing arrow; SOX2 subsequently induces SOX9 expression which initiates two processes (A,B). In (A), an increase in Wnt signaling enriches BCSCs which contributes to ETR. In (B), upregulation of FXY3D forms a positive feedback loop to enhance SOX9 action (C); FXY3D also bridges the formation of the ER-Src complex, resulting in activation of the SrC tyrosine kinase (D); Src activity facilitates BCSC enrichment (E).

\section{Strategy of Targeting BCSCs to Overcome Endocrine Resistance}

Based on current knowledge of the mechanisms regulating BCSCs in acquired resistance to endocrine therapy, a variety of approaches have been tested to target BCSCs in order to reduce ETR. Resistance to tamoxifen increases BCSCs and decreases c-FLIP (TRAIL inhibitor), leading to sensitization of the BCSCs to TRAIL-induced apoptosis; administration of recombinant TRAIL depletes BCSCs of tamoxifen resistant tumors in vitro and reduces the growth of MCF7-TamR cell-derived xenografts and tamoxifen-resistant PDX in vivo (Table 2) [232]. Pyrvinium pamoate was reported to inhibit Wnt signaling, downregulate key stem cell factors (NANOG, SOX2, and OCT4), attenuate the self-renewal of $\mathrm{CD} 44^{+} \mathrm{CD} 24^{- \text {low }}$ and ALDH+ BCSCs, and reduce MDA-MB-231 cell-derived xenograft growth (Table 2) [233]. A small molecule antagonist of CXCR1 Reparixin [234] is able to deplete ALDH ${ }^{+}$BCSCs in vitro and reduces xenograft growth and metastasis in vivo (Table 2) [205]. Consistent with a role of Src in promoting BCSCs under endocrine therapy (Figure 5) [228], combination of a Src inhibitor dasatinib and a BCL2 inhibitor venetoclaz induces apoptosis specifically in BCSCs (Table 2) [235]. Complex approaches to eliminate BCSCs have been investigated and were comprehensively reviewed [236-239].

The major mechanisms contributing to endocrine resistance include persistent ER signaling in the majority of resistant tumors, activation of the PI3K-AKT-mTOR pathway, and NOTCH signaling (Figure 3). These would be the ideal pathways for intervention in order to reduce endocrine resistance. However, we need to be cautious in targeting these pathways; strategies used should consider the negative cross-talks among these pathways (Figure 3). For example, in breast cancer targeting HER2 activates NOTCH1 [240] and inhibition of AKT and PI3K enhances NOTCH4 signaling (Figure 3) [241]. PI3K inhibition upregulates ER transcriptional activity (Figure 3) [242,243]. Similar reciprocal feedback has been reported between androgen receptor signaling and PI3K in prostate cancer, suggesting a common theme between hormone receptor signaling and PI3K in BC and prostate cancer [244].

Table 2. Strategy of targeting BCSCs associated with endocrine therapy resistance.

\begin{tabular}{ccccc}
\hline Method & BCSC & Model & Action & Ref. \\
\hline TRAIL & Tamoxifen $^{1}$ & Xenograft and PDX & Death receptor & [232] \\
\hline Pyrvinium pamoate & $\begin{array}{c}\mathrm{CD}^{+} 4^{+} \mathrm{CD}^{-/ \text {low }} \\
\mathrm{ALDH}^{+}\end{array}$ & Xenograft & Wnt inhibitor & {$[233]$} \\
\hline Reparixin & $\mathrm{ALDH}^{+}$ & Xenograft & $\begin{array}{c}\text { Agonist of } \\
\text { CXCR1/2 }\end{array}$ & {$[205]$} \\
\hline Dasatinib + venetoclaz & BCSCs & In vitro & $\begin{array}{c}\text { Src inhibitor } \\
\text { BCL2 inhibitor }\end{array}$ & {$[235]$} \\
\hline
\end{tabular}

${ }^{1}$ BCSCs were derived from tamoxifen resistant tumors. 


\section{A Dynamic Model of BCSC Regulation in the Settings of Hormone Therapy}

In accordance with an essential role of CSCs in cancer progression, CSCs are expected to evolve following cancer progression. As a result, CSCs display heterogeneity. This concept is supported by multiple pieces of evidence, including the intratumoral heterogeneity observed in multiple tumor types [245,246], the production of different types of xenograft tumors from a single cell lineage [247], and genome instability associated with CSCs [248]. Although a set of antigens (CD44, CD24, CD133, ALDH1, and others) have been identified in BCSCs (Table 1), it is highly possible that BCSCs can be negative for these markers. The common markers of CSCs are CD34 ${ }^{+} \mathrm{CD} 38^{-}$for $\mathrm{AML}$, and $\mathrm{CD} 133^{+}$, $\mathrm{CD}_{4}{ }^{+}$, and others for solid tumors, as these cells display higher abilities of tumor ignition in nude and NOD/SCID mice [37]. However, with NOD/SCID/IL2R $\gamma^{-/-}$mice that are more receptive to xenograft formation, cancer cells negative for these antigens initiate tumors with comparable efficiencies as those cells positive for the aforementioned markers [43,249-251].

The evolution of CSCs and BCSCs following cancer progression can be attributed to their lineage plasticity. For instance, recent developments favor the association of partial or hybrid EMT (the co-existence of both epithelial properties and mesenchymal characteristics) with CSCs [252]. In the squamous cell carcinoma of hair follicle, tumors with partial EMT display increases in plasticity and are more aggressiveness compared to carcinomas with full EMT [252-254]. In prostate cancer, tumor cells with hybrid EMT possess CSC properties and contribute to metastasis in vivo [255] and are correlated with metastasis in patients [256]. In a limited number of breast cancer patients examined $(n=11)$, circulating tumor cells (CTCs) positive for both epithelial and mesenchymal markers were observed [257]. In a later study involving 130 patients with metastatic BC including $68.5 \%$ of ER + vc BCs, CTCs positive for ALDH1+ and marked with both cytokeratins (CK8, 18, and 19, epithelial markers) and TWIST1 (a mesenchymal marker) were associated with lung metastasis as well as reductions in OS and progression-free survival [258]. In a primary BC cohort $(n=176)$, tumors positive for E-cadherin and vimentin (including 37\% of ER + ve BCs) were correlated with decreases in OS and disease free survival [259]. Collectively, evidence supports a dynamic regulation of CSCs during cancer progression, i.e., their appearance may not be limited to cells expressing certain proteins.

Human BCSCs are heterogeneous with cells marked with $\mathrm{CD} 44^{+} \mathrm{CD} 24^{-/ \mathrm{low}}, \mathrm{AHDH} 1^{+}, \mathrm{CD} 33^{+}$ (Table 1). The relationship among these individual BCSC populations remains largely unclear. Nonetheless, there is evidence suggesting that they are not identical at least for $\mathrm{CD} 44^{+} \mathrm{CD} 24^{-/ \text {low }}$ and ALDH1 ${ }^{+}$BCSCs (Figure 2A) [78]; this suggests evolution of BCSCs following the course of ETR (Figure 2A). With this knowledge, we can propose a model in which endocrine treatment induces BCSCs via dedifferentiation (Figure 6A); this model suggests a dynamic regulation of BCSC's stemness following ETR development and is different from the classical CSC model emphasizing the existence of BCSCs that drive ETR acquisition (Figure 6B). This model (Figure 6A) may explain the existence of CSCs in cancer cell lines that have been cultured for decades in the presence of $10 \%$ serum. This culture condition is unlikely able to sustain preexisting CSCs. At least for DU145 prostate cancer cell-derived spheres, they proliferated significantly slower in the presence of $10 \%$ serum than their non-stem counterparts [260]. The dynamic model (Figure 6A) indicates that the CSC potential instead of CSCs is preserved in cancer cell lines. This model is supported by a recent development [261]. In a mouse colorectal cancer model with CSCs marked with diphtheria toxin receptor (DTR) under control of the Lgr5 promoter, addition of diphtheria toxin ceased tumor growth as a result of ablation of Lgr5 ${ }^{+}$ CSCs [262,263]; diphtheria toxin removal reproduced $\mathrm{Lgr}^{+}$CSCs and resulted in tumor regrowth [263]. This research by de Sousa e Melo et al. strongly suggests for the first time that, at least in colorectal cancer, CSCs can be acquired through dedifferentiation from cancer cells. Nonetheless, the dynamic model (Figure 6A) and dedifferentiation-mediated acquisition of BCSCs during the course of endocrine resistance development does not exclude the possibility that the acquisition is from cancer cells with some intrinsic traits favoring BCSC dedifferentiation. Should this concept hold true, identification of these potential intrinsic properties will significantly advance our understanding of endocrine resistance particularly and cancer progression in general. 


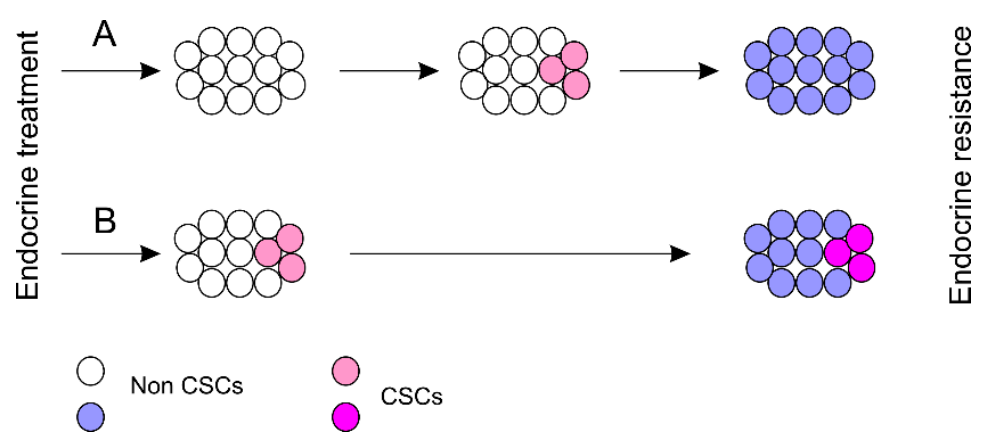

Figure 6. Models of BCSC regulation during ETR acquisition. (A) Endocrine treatment results in the acquisition of BCSCs through dedifferentiation (meddle cell population) which then produce tumors resistant to endocrine therapy (right cell population). (B) Endocrine therapy induces the pre-existing $\mathrm{BCSC}$ to generate resistant BCs containing a fraction of BCSCs.

\section{Conclusions}

The central properties of BCSCs with respect to their capacity of tumor initiation and plasticity clearly place them at the center for developing resistance to hormone therapy. The resistant tumors will progress to metastasis, the leading cause of cancer death $[264,265]$. BCSCs play a major role in metastasis, in part owing to their plasticity to make transitions between EMT $[266,267]$ and MET (mesenchymal-epithelial transition) [268,269], which are required for metastasis [31]. In this regard, the central role of BCSCs in the acquisition of ETR will set the stage for the subsequent metastasis. The contributions of BCSCs to endocrine resistance have been intensively investigated; currently we have a rich knowledge on the mechanisms regulating BCSCs following hormone treatment, which cover ER, growth factor receptor/PI3K-AKT-mTOR, NOTCH, Wnt, Hippo-YAP/TAZ, and stromal cues. These individual mechanisms have been investigated to control the resistance. However, translation of this knowledge to patients has been challenging.

A major challenge may lie in the heterogeneous nature of BCSCs and their dynamic regulation during the course of ETR progression (Figure 6A). It is an intriguing concept that CSCs are a property of cancer rather than a specific group of preexisting CSCs [263]. This knowledge implies targeting CSCs, BCSCs in the case of endocrine resistance, should consider the mechanisms and factors leading to CSC conversion.

Author Contributions: Conceptualization, D.R., M.R., A.K., M.P. and D.T.; material preparation, D.R., M.R. and X.L.; writing—original draft preparation, D.R., M.R. and D.T.; writing—review, all authors; writing editing-M.R. and D.T.; supervision, D.T.

Funding: D. Tang is supported by grants from Cancer Research Society, Canadian Cancer Society (grant \#: 319412), CIHR, and by funds from Urological Cancer Center for Research and Innovation (UCCRI).

Conflicts of Interest: The authors declare no conflict of interest.

\section{References}

1. Ferlay, J.; Soerjomataram, I.; Dikshit, R.; Eser, S.; Mathers, C.; Rebelo, M.; Parkin, D.M.; Forman, D.; Bray, F. Cancer incidence and mortality worldwide: Sources, methods and major patterns in globocan 2012. Int. J. Cancer 2015, 136, E359-E386. [CrossRef] [PubMed]

2. Siegel, R.L.; Miller, K.D.; Jemal, A. Cancer statistics, 2018. CA: Cancer J. Clin. 2018, 68, 7-30. [CrossRef] [PubMed]

3. Ojo, D.; Wei, F.; Liu, Y.; Wang, E.; Zhang, H.; Lin, X.; Wong, N.; Bane, A.; Tang, D. Factors promoting tamoxifen resistance in breast cancer via stimulating breast cancer stem cell expansion. Curr. Med. Chem. 2015, 22, 2360-2374. [CrossRef] [PubMed]

4. Clark, G.M.; Osborne, C.K.; McGuire, W.L. Correlations between estrogen receptor, progesterone receptor, and patient characteristics in human breast cancer. J. Clin. Oncol. 1984, 2, 1102-1109. [CrossRef] [PubMed] 
5. Harvey, J.M.; Clark, G.M.; Osborne, C.K.; Allred, D.C. Estrogen receptor status by immunohistochemistry is superior to the ligand-binding assay for predicting response to adjuvant endocrine therapy in breast cancer. J. Clin. Oncol. 1999, 17, 1474-1481. [CrossRef] [PubMed]

6. Keeling, J.W.; Ozer, E.; King, G.; Walker, F. Oestrogen receptor alpha in female fetal, infant, and child mammary tissue. J. Pathol. 2000, 191, 449-451. [CrossRef]

7. Korach, K.S.; Couse, J.F.; Curtis, S.W.; Washburn, T.F.; Lindzey, J.; Kimbro, K.S.; Eddy, E.M.; Migliaccio, S.; Snedeker, S.M.; Lubahn, D.B.; et al. Estrogen receptor gene disruption: Molecular characterization and experimental and clinical phenotypes. Recent Prog. Horm. Res. 1996, 51, 159-186. [PubMed]

8. Carroll, J.S.; Liu, X.S.; Brodsky, A.S.; Li, W.; Meyer, C.A.; Szary, A.J.; Eeckhoute, J.; Shao, W.; Hestermann, E.V.; Geistlinger, T.R.; et al. Chromosome-wide mapping of estrogen receptor binding reveals long-range regulation requiring the forkhead protein foxa1. Cell 2005, 122, 33-43. [CrossRef] [PubMed]

9. Musgrove, E.A.; Caldon, C.E.; Barraclough, J.; Stone, A.; Sutherland, R.L. Cyclin d as a therapeutic target in cancer. Nat. Rev. Cancer 2011, 11, 558-572. [CrossRef]

10. Eeckhoute, J.; Carroll, J.S.; Geistlinger, T.R.; Torres-Arzayus, M.I.; Brown, M. A cell-type-specific transcriptional network required for estrogen regulation of cyclin $\mathrm{d} 1$ and cell cycle progression in breast cancer. Genes Dev. 2006, 20, 2513-2526. [CrossRef]

11. Dong, L.; Wang, W.; Wang, F.; Stoner, M.; Reed, J.C.; Harigai, M.; Samudio, I.; Kladde, M.P.; Vyhlidal, C.; Safe, S. Mechanisms of transcriptional activation of bcl-2 gene expression by 17 beta-estradiol in breast cancer cells. J. Biol. Chem. 1999, 274, 32099-32107. [CrossRef] [PubMed]

12. Seeger, H.; Wallwiener, D.; Mueck, A.O. Different effects of estradiol and various antiestrogens on tnf-alpha-induced changes of biochemical markers for growth and invasion of human breast cancer cells. Life Sci. 2006, 78, 1464-1468. [CrossRef] [PubMed]

13. Sweeney, E.E.; McDaniel, R.E.; Maximov, P.Y.; Fan, P.; Jordan, V.C. Models and mechanisms of acquired antihormone resistance in breast cancer: Significant clinical progress despite limitations. Horm. Mol. Biol. Clin. Investig. 2012, 9, 143-163. [CrossRef] [PubMed]

14. Wakeling, A.E.; Dukes, M.; Bowler, J. A potent specific pure antiestrogen with clinical potential. Cancer Res. 1991, 51, 3867-3873. [PubMed]

15. Johnston, S.J.; Cheung, K.L. Fulvestrant - a novel endocrine therapy for breast cancer. Curr. Med. Chem. 2010, 17, 902-914. [CrossRef] [PubMed]

16. Osborne, C.K. Aromatase inhibitors in relation to other forms of endocrine therapy for breast cancer. Endocr. Relat. Cancer 1999, 6, 271-276. [CrossRef]

17. Buzdar, A.U. Aromatase inhibitors in breast cancer therapy. Clin. Breast Cancer 2003, 4 (Suppl. 2), S84-S88. [CrossRef]

18. Osborne, C.K.; Schiff, R.; Arpino, G.; Lee, A.S.; Hilsenbeck, V.G. Endocrine responsiveness: Understanding how progesterone receptor can be used to select endocrine therapy. Breast 2005, 14, 458-465. [CrossRef]

19. Li, J.; Wang, Z.; Shao, Z. Fulvestrant in the treatment of hormone receptor-positive/human epidermal growth factor receptor 2-negative advanced breast cancer: A review. Cancer Med. 2019, 8, 1943-1957. [CrossRef]

20. Arpino, G.; Weiss, H.; Lee, A.V.; Schiff, R.; De Placido, S.; Osborne, C.K.; Elledge, R.M. Estrogen receptor-positive, progesterone receptor-negative breast cancer: Association with growth factor receptor expression and tamoxifen resistance. J. Natl. Cancer Inst. 2005, 97, 1254-1261. [CrossRef]

21. Rakha, E.A.; El-Sayed, M.E.; Green, A.R.; Paish, E.C.; Powe, D.G.; Gee, J.; Nicholson, R.I.; Lee, A.H.; Robertson, J.F.; Ellis, I.O. Biologic and clinical characteristics of breast cancer with single hormone receptor positive phenotype. J. Clin. Oncol. 2007, 25, 4772-4778. [CrossRef] [PubMed]

22. Early Breast Cancer Trialists' Collaborative Group. Effects of chemotherapy and hormonal therapy for early breast cancer on recurrence and 15-year survival: An overview of the randomised trials. Lancet 2005, 365, 1687-1717.

23. Musgrove, E.A.; Sutherland, R.L. Biological determinants of endocrine resistance in breast cancer. Nat. Rev. Cancer 2009, 9, 631-643. [CrossRef] [PubMed]

24. Badia, E.; Oliva, J.; Balaguer, P.; Cavailles, V. Tamoxifen resistance and epigenetic modifications in breast cancer cell lines. Curr. Med. Chem. 2007, 14, 3035-3045. [CrossRef] [PubMed]

25. Ring, A.; Dowsett, M. Mechanisms of tamoxifen resistance. Endocr. Relat. Cancer 2004, 11, 643-658. [CrossRef] [PubMed] 
26. Schiff, R.; Massarweh, S.; Shou, J.; Osborne, C.K. Breast cancer endocrine resistance: How growth factor signaling and estrogen receptor coregulators modulate response. Clin. Cancer Res. 2003, 9, 447S-454S. [PubMed]

27. Ignatiadis, M.; Sotiriou, C. Luminal breast cancer: From biology to treatment. Nat. Rev. Clin. Oncol. 2013, 10, 494-506. [CrossRef] [PubMed]

28. Zhang, X.H.; Giuliano, M.; Trivedi, M.V.; Schiff, R.; Osborne, C.K. Metastasis dormancy in estrogen receptor-positive breast cancer. Clin. Cancer Res. 2013, 19, 6389-6397. [CrossRef] [PubMed]

29. Cardoso, F.; Costa, A.; Norton, L.; Senkus, E.; Aapro, M.; Andre, F.; Barrios, C.H.; Bergh, J.; Biganzoli, L.; Blackwell, K.L.; et al. Eso-esmo 2nd international consensus guidelines for advanced breast cancer (abc2) dagger. Ann. Oncol. 2014, 25, 1871-1888. [CrossRef]

30. Cardoso, F.; Costa, A.; Norton, L.; Senkus, E.; Aapro, M.; Andre, F.; Barrios, C.H.; Bergh, J.; Biganzoli, L.; Blackwell, K.L.; et al. Eso-esmo 2nd international consensus guidelines for advanced breast cancer (abc2). Breast 2014, 23, 489-502. [CrossRef]

31. Mei, W.; Lin, X.; Kapoor, A.; Gu, Y.; Zhao, K.; Tang, D. The contributions of prostate cancer stem cells in prostate cancer initiation and metastasis. Cancers 2019, 11, 434. [CrossRef] [PubMed]

32. Shamseer, L.; Moher, D.; Clarke, M.; Ghersi, D.; Liberati, A.; Petticrew, M.; Shekelle, P.; Stewart, L.A.; Group, P.-P. Preferred reporting items for systematic review and meta-analysis protocols (prisma-p) 2015: Elaboration and explanation. BMJ 2015, 349, g7647. [CrossRef] [PubMed]

33. Moher, D.; Shamseer, L.; Clarke, M.; Ghersi, D.; Liberati, A.; Petticrew, M.; Shekelle, P.; Stewart, L.A.; Group, P.-P. Preferred reporting items for systematic review and meta-analysis protocols (prisma-p) 2015 statement. Syst. Rev. 2015, 4, 1. [CrossRef] [PubMed]

34. Lapidot, T.; Sirard, C.; Vormoor, J.; Murdoch, B.; Hoang, T.; Caceres-Cortes, J.; Minden, M.; Paterson, B.; Caligiuri, M.A.; Dick, J.E. A cell initiating human acute myeloid leukaemia after transplantation into scid mice. Nature 1994, 367, 645-648. [CrossRef]

35. Al-Hajj, M.; Wicha, M.S.; Benito-Hernandez, A.; Morrison, S.J.; Clarke, M.F. Prospective identification of tumorigenic breast cancer cells. Proc. Natl. Acad. Sci. USA 2003, 100, 3983-3988. [CrossRef]

36. Baccelli, I.; Trumpp, A. The evolving concept of cancer and metastasis stem cells. J. Cell Biol. 2012, 198, 281-293. [CrossRef]

37. Kreso, A.; Dick, J.E. Evolution of the cancer stem cell model. Cell Stem Cell 2014, 14, 275-291. [CrossRef]

38. She, J.J.; Zhang, P.G.; Wang, Z.M.; Gan, W.M.; Che, X.M. Identification of side population cells from bladder cancer cells by dyecycle violet staining. Cancer Biol. Ther. 2008, 7, 1663-1668. [CrossRef]

39. Singh, S.K.; Hawkins, C.; Clarke, I.D.; Squire, J.A.; Bayani, J.; Hide, T.; Henkelman, R.M.; Cusimano, M.D.; Dirks, P.B. Identification of human brain tumour initiating cells. Nature 2004, 432, 396-401. [CrossRef]

40. Ovalle, S.; Gutierrez-Lopez, M.D.; Olmo, N.; Turnay, J.; Lizarbe, M.A.; Majano, P.; Molina-Jimenez, F.; Lopez-Cabrera, M.; Yanez-Mo, M.; Sanchez-Madrid, F.; et al. The tetraspanin cd9 inhibits the proliferation and tumorigenicity of human colon carcinoma cells. Int. J. Cancer 2007, 121, 2140-2152. [CrossRef]

41. Ricci-Vitiani, L.; Lombardi, D.G.; Pilozzi, E.; Biffoni, M.; Todaro, M.; Peschle, C.; De Maria, R. Identification and expansion of human colon-cancer-initiating cells. Nature 2007, 445, 111-115. [CrossRef] [PubMed]

42. Prince, M.E.; Sivanandan, R.; Kaczorowski, A.; Wolf, G.T.; Kaplan, M.J.; Dalerba, P.; Weissman, I.L.; Clarke, M.F.; Ailles, L.E. Identification of a subpopulation of cells with cancer stem cell properties in head and neck squamous cell carcinoma. Proc. Natl. Acad. Sci. USA 2007, 104, 973-978. [CrossRef] [PubMed]

43. Eramo, A.; Lotti, F.; Sette, G.; Pilozzi, E.; Biffoni, M.; Di Virgilio, A.; Conticello, C.; Ruco, L.; Peschle, C.; De Maria, R. Identification and expansion of the tumorigenic lung cancer stem cell population. Cell Death Differ. 2008, 15, 504-514. [CrossRef] [PubMed]

44. Fang, D.; Nguyen, T.K.; Leishear, K.; Finko, R.; Kulp, A.N.; Hotz, S.; Van Belle, P.A.; Xu, X.; Elder, D.E.; Herlyn, M. A tumorigenic subpopulation with stem cell properties in melanomas. Cancer Res. 2005, 65, 9328-9337. [CrossRef] [PubMed]

45. Hermann, P.C.; Huber, S.L.; Herrler, T.; Aicher, A.; Ellwart, J.W.; Guba, M.; Bruns, C.J.; Heeschen, C. Distinct populations of cancer stem cells determine tumor growth and metastatic activity in human pancreatic cancer. Cell Stem Cell 2007, 1, 313-323. [CrossRef] [PubMed]

46. Li, C.; Heidt, D.G.; Dalerba, P.; Burant, C.F.; Zhang, L.; Adsay, V.; Wicha, M.; Clarke, M.F.; Simeone, D.M. Identification of pancreatic cancer stem cells. Cancer Res. 2007, 67, 1030-1037. [CrossRef] [PubMed] 
47. Collins, A.T.; Berry, P.A.; Hyde, C.; Stower, M.J.; Maitland, N.J. Prospective identification of tumorigenic prostate cancer stem cells. Cancer Res. 2005, 65, 10946-10951. [CrossRef] [PubMed]

48. Wu, C.; Wei, Q.; Utomo, V.; Nadesan, P.; Whetstone, H.; Kandel, R.; Wunder, J.S.; Alman, B.A. Side population cells isolated from mesenchymal neoplasms have tumor initiating potential. Cancer Res. 2007, 67, 8216-8222. [CrossRef]

49. Visvader, J.E.; Lindeman, G.J. Cancer stem cells in solid tumours: Accumulating evidence and unresolved questions. Nat. Rev. Cancer 2008, 8, 755-768. [CrossRef]

50. Inman, J.L.; Robertson, C.; Mott, J.D.; Bissell, M.J. Mammary gland development: Cell fate specification, stem cells and the microenvironment. Development 2015, 142, 1028-1042. [CrossRef]

51. Kordon, E.C.; Smith, G.H. An entire functional mammary gland may comprise the progeny from a single cell. Development 1998, 125, 1921-1930. [PubMed]

52. Daniel, C.W.; Smith, G.H. The mammary gland: A model for development. J. Mammary Gland Biol. Neoplasia 1999, 4, 3-8. [CrossRef] [PubMed]

53. Van Keymeulen, A.; Rocha, A.S.; Ousset, M.; Beck, B.; Bouvencourt, G.; Rock, J.; Sharma, N.; Dekoninck, S.; Blanpain, C. Distinct stem cells contribute to mammary gland development and maintenance. Nature 2011, 479, 189-193. [CrossRef] [PubMed]

54. van Amerongen, R.; Bowman, A.N.; Nusse, R. Developmental stage and time dictate the fate of wnt/beta-catenin-responsive stem cells in the mammary gland. Cell Stem Cell 2012, 11, 387-400. [CrossRef] [PubMed]

55. Rios, A.C.; Fu, N.Y.; Lindeman, G.J.; Visvader, J.E. In situ identification of bipotent stem cells in the mammary gland. Nature 2014, 506, 322-327. [CrossRef] [PubMed]

56. Shackleton, M.; Vaillant, F.; Simpson, K.J.; Stingl, J.; Smyth, G.K.; Asselin-Labat, M.L.; Wu, L.; Lindeman, G.J.; Visvader, J.E. Generation of a functional mammary gland from a single stem cell. Nature 2006, 439, 84-88. [CrossRef] [PubMed]

57. Fu, N.Y.; Rios, A.C.; Pal, B.; Law, C.W.; Jamieson, P.; Liu, R.; Vaillant, F.; Jackling, F.; Liu, K.H.; Smyth, G.K.; et al. Identification of quiescent and spatially restricted mammary stem cells that are hormone responsive. Nat. Cell Biol. 2017, 19, 164-176. [CrossRef] [PubMed]

58. Cai, S.; Kalisky, T.; Sahoo, D.; Dalerba, P.; Feng, W.; Lin, Y.; Qian, D.; Kong, A.; Yu, J.; Wang, F.; et al. A quiescent bcl11b high stem cell population is required for maintenance of the mammary gland. Cell Stem Cell 2017, 20, 247-260. [CrossRef]

59. Eirew, P.; Stingl, J.; Raouf, A.; Turashvili, G.; Aparicio, S.; Emerman, J.T.; Eaves, C.J. A method for quantifying normal human mammary epithelial stem cells with in vivo regenerative ability. Nat. Med. 2008, 14, 1384-1389. [CrossRef]

60. Ginestier, C.; Hur, M.H.; Charafe-Jauffret, E.; Monville, F.; Dutcher, J.; Brown, M.; Jacquemier, J.; Viens, P.; Kleer, C.G.; Liu, S.; et al. Aldh1 is a marker of normal and malignant human mammary stem cells and a predictor of poor clinical outcome. Cell Stem Cell 2007, 1, 555-567. [CrossRef]

61. Lee, E.; Piranlioglu, R.; Wicha, M.S.; Korkaya, H. Plasticity and potency of mammary stem cell subsets during mammary gland development. Int. J. Mol. Sci. 2019, 20, 2357. [CrossRef] [PubMed]

62. Tian, H.; Biehs, B.; Warming, S.; Leong, K.G.; Rangell, L.; Klein, O.D.; de Sauvage, F.J. A reserve stem cell population in small intestine renders lgr5-positive cells dispensable. Nature 2011, 478, 255-259. [CrossRef] [PubMed]

63. Gomez-Miragaya, J.; Gonzalez-Suarez, E. Tumor-initiating cd49f cells are a hallmark of chemoresistant triple negative breast cancer. Mol. Cell. Oncol. 2017, 4, e1338208. [CrossRef]

64. Sansone, P.; Ceccarelli, C.; Berishaj, M.; Chang, Q.; Rajasekhar, V.K.; Perna, F.; Bowman, R.L.; Vidone, M.; Daly, L.; Nnoli, J.; et al. Self-renewal of cd133(hi) cells by il6/notch3 signalling regulates endocrine resistance in metastatic breast cancer. Nat. Commun. 2016, 7, 10442. [CrossRef] [PubMed]

65. Liu, T.J.; Sun, B.C.; Zhao, X.L.; Zhao, X.M.; Sun, T.; Gu, Q.; Yao, Z.; Dong, X.Y.; Zhao, N.; Liu, N. Cd133+ cells with cancer stem cell characteristics associates with vasculogenic mimicry in triple-negative breast cancer. Oncogene 2013, 32, 544-553. [CrossRef]

66. Tsang, J.Y.; Huang, Y.H.; Luo, M.H.; Ni, Y.B.; Chan, S.K.; Lui, P.C.; Yu, A.M.; Tan, P.H.; Tse, G.M. Cancer stem cell markers are associated with adverse biomarker profiles and molecular subtypes of breast cancer. Breast Cancer Res. Treat. 2012, 136, 407-417. [CrossRef] 
67. Ricardo, S.; Vieira, A.F.; Gerhard, R.; Leitao, D.; Pinto, R.; Cameselle-Teijeiro, J.F.; Milanezi, F.; Schmitt, F.; Paredes, J. Breast cancer stem cell markers cd44, cd24 and aldh1: Expression distribution within intrinsic molecular subtype. J. Clin. Pathol. 2011, 64, 937-946. [CrossRef]

68. Miyoshi, Y.; Shien, T.; Ogiya, A.; Ishida, N.; Yamazaki, K.; Horii, R.; Horimoto, Y.; Masuda, N.; Yasojima, H.; Inao, T.; et al. Differences in expression of the cancer stem cell marker aldehyde dehydrogenase 1 among estrogen receptor-positive/human epidermal growth factor receptor type 2-negative breast cancer cases with early, late, and no recurrence. Breast Cancer Res. 2016, 18, 73. [CrossRef]

69. Tanei, T.; Morimoto, K.; Shimazu, K.; Kim, S.J.; Tanji, Y.; Taguchi, T.; Tamaki, Y.; Noguchi, S. Association of breast cancer stem cells identified by aldehyde dehydrogenase 1 expression with resistance to sequential paclitaxel and epirubicin-based chemotherapy for breast cancers. Clin. Cancer Res. 2009, 15, 4234-4241. [CrossRef]

70. Wang, X.; Wang, G.; Zhao, Y.; Liu, X.; Ding, Q.; Shi, J.; Ding, Y.; Wang, S. Stat3 mediates resistance of cd44(+)cd24(-/low) breast cancer stem cells to tamoxifen in vitro. J. Biomed. Res. 2012, 26, 325-335. [CrossRef]

71. Piva, M.; Domenici, G.; Iriondo, O.; Rabano, M.; Simoes, B.M.; Comaills, V.; Barredo, I.; Lopez-Ruiz, J.A.; Zabalza, I.; Kypta, R.; et al. Sox2 promotes tamoxifen resistance in breast cancer cells. EMBO Mol. Med. 2014, 6, 66-79. [CrossRef] [PubMed]

72. Dubrovska, A.; Hartung, A.; Bouchez, L.C.; Walker, J.R.; Reddy, V.A.; Cho, C.Y.; Schultz, P.G. Cxcr4 activation maintains a stem cell population in tamoxifen-resistant breast cancer cells through ahr signalling. Br. J. Cancer 2012, 107, 43-52. [CrossRef] [PubMed]

73. Liu, H.; Zhang, H.W.; Sun, X.F.; Guo, X.H.; He, Y.N.; Cui, S.D.; Fan, Q.X. Tamoxifen-resistant breast cancer cells possess cancer stem-like cell properties. Chin. Med. J. 2013, 126, 3030-3034. [PubMed]

74. Raffo, D.; Berardi, D.E.; Pontiggia, O.; Todaro, L.; de Kier Joffe, E.B.; Simian, M. Tamoxifen selects for breast cancer cells with mammosphere forming capacity and increased growth rate. Breast Cancer Res. Treat. 2013, 142, 537-548. [CrossRef] [PubMed]

75. Creighton, C.J.; Li, X.; Landis, M.; Dixon, J.M.; Neumeister, V.M.; Sjolund, A.; Rimm, D.L.; Wong, H.; Rodriguez, A.; Herschkowitz, J.I.; et al. Residual breast cancers after conventional therapy display mesenchymal as well as tumor-initiating features. Proc. Natl. Acad. Sci. USA 2009, 106, 13820-13825. [CrossRef] [PubMed]

76. Simoes, B.M.; O’Brien, C.S.; Eyre, R.; Silva, A.; Yu, L.; Sarmiento-Castro, A.; Alferez, D.G.; Spence, K.; Santiago-Gomez, A.; Chemi, F.; et al. Anti-estrogen resistance in human breast tumors is driven by jag1-notch4-dependent cancer stem cell activity. Cell Rep. 2015, 12, 1968-1977. [CrossRef] [PubMed]

77. Ojo, D.; Lin, X.; Wu, Y.; Cockburn, J.; Bane, A.; Tang, D. Polycomb complex protein bmi1 confers resistance to tamoxifen in estrogen receptor positive breast cancer. Cancer Lett. 2018, 426, 4-13. [CrossRef] [PubMed]

78. Liu, S.; Cong, Y.; Wang, D.; Sun, Y.; Deng, L.; Liu, Y.; Martin-Trevino, R.; Shang, L.; McDermott, S.P.; Landis, M.D.; et al. Breast cancer stem cells transition between epithelial and mesenchymal states reflective of their normal counterparts. Stem Cell Rep. 2014, 2, 78-91. [CrossRef]

79. Hammond, M.E.; Hayes, D.F.; Dowsett, M.; Allred, D.C.; Hagerty, K.L.; Badve, S.; Fitzgibbons, P.L.; Francis, G.; Goldstein, N.S.; Hayes, M.; et al. American society of clinical oncology/college of american pathologists guideline recommendations for immunohistochemical testing of estrogen and progesterone receptors in breast cancer. J. Clin. Oncol. 2010, 28, 2784-2795. [CrossRef]

80. Johnston, S.R.; Saccani-Jotti, G.; Smith, I.E.; Salter, J.; Newby, J.; Coppen, M.; Ebbs, S.R.; Dowsett, M. Changes in estrogen receptor, progesterone receptor, and ps2 expression in tamoxifen-resistant human breast cancer. Cancer Res. 1995, 55, 3331-3338.

81. Gutierrez, M.C.; Detre, S.; Johnston, S.; Mohsin, S.K.; Shou, J.; Allred, D.C.; Schiff, R.; Osborne, C.K.; Dowsett, M. Molecular changes in tamoxifen-resistant breast cancer: Relationship between estrogen receptor, her-2, and p38 mitogen-activated protein kinase. J. Clin. Oncol. 2005, 23, 2469-2476. [CrossRef] [PubMed]

82. Dowsett, M. Overexpression of her-2 as a resistance mechanism to hormonal therapy for breast cancer. Endocr. Relat. Cancer 2001, 8, 191-195. [CrossRef]

83. Hull, D.F.; Clark, G.M.; Osborne, C.K.; Chamness, G.C.; Knight, W.A.; McGuire, W.L. Multiple estrogen receptor assays in human breast cancer. Cancer Res. 1983, 43, 413-416. [PubMed]

84. Herman, M.E.; Katzenellenbogen, B.S. Response-specific antiestrogen resistance in a newly characterized mcf-7 human breast cancer cell line resulting from long-term exposure to trans-hydroxytamoxifen. J. Steroid Biochem. Mol. Biol. 1996, 59, 121-134. [CrossRef] 
85. Kabos, P.; Finlay-Schultz, J.; Li, C.; Kline, E.; Finlayson, C.; Wisell, J.; Manuel, C.A.; Edgerton, S.M.; Harrell, J.C.; Elias, A.; et al. Patient-derived luminal breast cancer xenografts retain hormone receptor heterogeneity and help define unique estrogen-dependent gene signatures. Breast Cancer Res. Treat. 2012, 135, 415-432. [CrossRef] [PubMed]

86. Osborne, C.K.; Pippen, J.; Jones, S.E.; Parker, L.M.; Ellis, M.; Come, S.; Gertler, S.Z.; May, J.T.; Burton, G.; Dimery, I.; et al. Double-blind, randomized trial comparing the efficacy and tolerability of fulvestrant versus anastrozole in postmenopausal women with advanced breast cancer progressing on prior endocrine therapy: Results of a north american trial. J. Clin. Oncol. 2002, 20, 3386-3395. [CrossRef] [PubMed]

87. Howell, A.; Pippen, J.; Elledge, R.M.; Mauriac, L.; Vergote, I.; Jones, S.E.; Come, S.E.; Osborne, C.K.; Robertson, J.F. Fulvestrant versus anastrozole for the treatment of advanced breast carcinoma: A prospectively planned combined survival analysis of two multicenter trials. Cancer 2005, 104, 236-239. [CrossRef]

88. Fuqua, S.A. The role of estrogen receptors in breast cancer metastasis. J. Mammary Gland Biol. Neoplasia 2001, 6, 407-417. [CrossRef]

89. Giguere, V. Estrogen receptor mutations in breast cancer-an anticipated "rediscovery?". Mol. Endocrinol. 2014, 28, 427-428. [CrossRef]

90. Shaw, L.E.; Sadler, A.J.; Pugazhendhi, D.; Darbre, P.D. Changes in oestrogen receptor-alpha and -beta during progression to acquired resistance to tamoxifen and fulvestrant (faslodex, ici 182,780) in mcf7 human breast cancer cells. J. Steroid Biochem. Mol. Biol. 2006, 99, 19-32. [CrossRef]

91. Holst, F.; Stahl, P.R.; Ruiz, C.; Hellwinkel, O.; Jehan, Z.; Wendland, M.; Lebeau, A.; Terracciano, L.; Al-Kuraya, K.; Janicke, F.; et al. Estrogen receptor alpha (esr1) gene amplification is frequent in breast cancer. Nat. Genet. 2007, 39, 655-660. [CrossRef] [PubMed]

92. Brown, L.A.; Hoog, J.; Chin, S.F.; Tao, Y.; Zayed, A.A.; Chin, K.; Teschendorff, A.E.; Quackenbush, J.F.; Marioni, J.C.; Leung, S.; et al. Esr1 gene amplification in breast cancer: A common phenomenon? Nat. Genet. 2008, 40, 806-807. [CrossRef] [PubMed]

93. Szostakowska, M.; Trebinska-Stryjewska, A.; Grzybowska, E.A.; Fabisiewicz, A. Resistance to endocrine therapy in breast cancer: Molecular mechanisms and future goals. Breast Cancer Res. Treat. 2019, 173, 489-497. [CrossRef] [PubMed]

94. Tomita, S.; Zhang, Z.; Nakano, M.; Ibusuki, M.; Kawazoe, T.; Yamamoto, Y.; Iwase, H. Estrogen receptor alpha gene esr1 amplification may predict endocrine therapy responsiveness in breast cancer patients. Cancer Sci. 2009, 100, 1012-1017. [CrossRef] [PubMed]

95. Nielsen, K.V.; Ejlertsen, B.; Muller, S.; Moller, S.; Rasmussen, B.B.; Balslev, E.; Laenkholm, A.V.; Christiansen, P.; Mouridsen, H.T. Amplification of esr1 may predict resistance to adjuvant tamoxifen in postmenopausal patients with hormone receptor positive breast cancer. Breast Cancer Res. Treat. 2011, 127, 345-355. [CrossRef]

96. Lin, C.H.; Liu, J.M.; Lu, Y.S.; Lan, C.; Lee, W.C.; Kuo, K.T.; Wang, C.C.; Chang, D.Y.; Huang, C.S.; Cheng, A.L. Clinical significance of esr1 gene copy number changes in breast cancer as measured by fluorescence in situ hybridisation. J. Clin. Pathol. 2013, 66, 140-145. [CrossRef] [PubMed]

97. Basudan, A.; Priedigkeit, N.; Hartmaier, R.J.; Sokol, E.S.; Bahreini, A.; Watters, R.J.; Boisen, M.M.; Bhargava, R.; Weiss, K.R.; Karsten, M.M.; et al. Frequent esr1 and cdk pathway copy-number alterations in metastatic breast cancer. Mol. Cancer Res. 2019, 17, 457-468. [CrossRef]

98. Magnani, L.; Frige, G.; Gadaleta, R.M.; Corleone, G.; Fabris, S.; Kempe, M.H.; Verschure, P.J.; Barozzi, I.; Vircillo, V.; Hong, S.P.; et al. Acquired cyp19a1 amplification is an early specific mechanism of aromatase inhibitor resistance in eralpha metastatic breast cancer. Nat. Genet. 2017, 49, 444-450. [CrossRef]

99. Nguyen, V.T.; Barozzi, I.; Faronato, M.; Lombardo, Y.; Steel, J.H.; Patel, N.; Darbre, P.; Castellano, L.; Gyorffy, B.; Woodley, L.; et al. Differential epigenetic reprogramming in response to specific endocrine therapies promotes cholesterol biosynthesis and cellular invasion. Nat. Commun. 2015, 6, 10044. [CrossRef]

100. Pejerrey, S.M.; Dustin, D.; Kim, J.A.; Gu, G.; Rechoum, Y.; Fuqua, S.A.W. The impact of esr1 mutations on the treatment of metastatic breast cancer. Horm. Cancer 2018, 9, 215-228. [CrossRef]

101. Weis, K.E.; Ekena, K.; Thomas, J.A.; Lazennec, G.; Katzenellenbogen, B.S. Constitutively active human estrogen receptors containing amino acid substitutions for tyrosine 537 in the receptor protein. Mol. Endocrinol. 1996, 10, 1388-1398. [PubMed]

102. Zhang, Q.X.; Borg, A.; Wolf, D.M.; Oesterreich, S.; Fuqua, S.A. An estrogen receptor mutant with strong hormone-independent activity from a metastatic breast cancer. Cancer Res. 1997, 57, 1244-1249. [PubMed] 
103. Toy, W.; Shen, Y.; Won, H.; Green, B.; Sakr, R.A.; Will, M.; Li, Z.; Gala, K.; Fanning, S.; King, T.A.; et al. Esr1 ligand-binding domain mutations in hormone-resistant breast cancer. Nat. Genet. 2013, 45, 1439-1445. [CrossRef] [PubMed]

104. Robinson, D.R.; Wu, Y.M.; Vats, P.; Su, F.; Lonigro, R.J.; Cao, X.; Kalyana-Sundaram, S.; Wang, R.; Ning, Y.; Hodges, L.; et al. Activating esr1 mutations in hormone-resistant metastatic breast cancer. Nat. Genet. 2013, 45, 1446-1451. [CrossRef] [PubMed]

105. Merenbakh-Lamin, K.; Ben-Baruch, N.; Yeheskel, A.; Dvir, A.; Soussan-Gutman, L.; Jeselsohn, R.; Yelensky, R.; Brown, M.; Miller, V.A.; Sarid, D.; et al. D538g mutation in estrogen receptor-alpha: A novel mechanism for acquired endocrine resistance in breast cancer. Cancer Res. 2013, 73, 6856-6864. [CrossRef] [PubMed]

106. Jeselsohn, R.; Yelensky, R.; Buchwalter, G.; Frampton, G.; Meric-Bernstam, F.; Gonzalez-Angulo, A.M.; Ferrer-Lozano, J.; Perez-Fidalgo, J.A.; Cristofanilli, M.; Gomez, H.; et al. Emergence of constitutively active estrogen receptor-alpha mutations in pretreated advanced estrogen receptor-positive breast cancer. Clin. Cancer Res. 2014, 20, 1757-1767. [CrossRef] [PubMed]

107. Wang, P.; Bahreini, A.; Gyanchandani, R.; Lucas, P.C.; Hartmaier, R.J.; Watters, R.J.; Jonnalagadda, A.R.; Trejo Bittar, H.E.; Berg, A.; Hamilton, R.L.; et al. Sensitive detection of mono- and polyclonal esr1 mutations in primary tumors, metastatic lesions, and cell-free DNA of breast cancer patients. Clin. Cancer Res. 2016, 22, 1130-1137. [CrossRef] [PubMed]

108. Gelsomino, L.; Panza, S.; Giordano, C.; Barone, I.; Gu, G.; Spina, E.; Catalano, S.; Fuqua, S.; Ando, S. Mutations in the estrogen receptor alpha hormone binding domain promote stem cell phenotype through notch activation in breast cancer cell lines. Cancer Lett. 2018, 428, 12-20. [CrossRef] [PubMed]

109. Rayala, S.K.; Talukder, A.H.; Balasenthil, S.; Tharakan, R.; Barnes, C.J.; Wang, R.A.; Aldaz, C.M.; Khan, S.; Kumar, R. P21-activated kinase 1 regulation of estrogen receptor-alpha activation involves serine 305 activation linked with serine 118 phosphorylation. Cancer Res. 2006, 66, 1694-1701. [CrossRef]

110. Veeraraghavan, J.; Tan, Y.; Cao, X.X.; Kim, J.A.; Wang, X.; Chamness, G.C.; Maiti, S.N.; Cooper, L.J.; Edwards, D.P.; Contreras, A.; et al. Recurrent esr1-ccdc170 rearrangements in an aggressive subset of oestrogen receptor-positive breast cancers. Nat. Commun. 2014, 5, 4577. [CrossRef]

111. Giltnane, J.M.; Hutchinson, K.E.; Stricker, T.P.; Formisano, L.; Young, C.D.; Estrada, M.V.; Nixon, M.J.; Du, L.; Sanchez, V.; Ericsson, P.G.; et al. Genomic profiling of er (+) breast cancers after short-term estrogen suppression reveals alterations associated with endocrine resistance. Sci. Transl. Med. 2017, 9, eaai7993. [CrossRef] [PubMed]

112. Li, S.; Shen, D.; Shao, J.; Crowder, R.; Liu, W.; Prat, A.; He, X.; Liu, S.; Hoog, J.; Lu, C.; et al. Endocrine-therapy-resistant esr1 variants revealed by genomic characterization of breast-cancer-derived xenografts. Cell Rep. 2013, 4, 1116-1130. [CrossRef] [PubMed]

113. Lei, J.T.; Shao, J.; Zhang, J.; Iglesia, M.; Chan, D.W.; Cao, J.; Anurag, M.; Singh, P.; He, X.; Kosaka, Y.; et al. Functional annotation of esr1 gene fusions in estrogen receptor-positive breast cancer. Cell Rep. 2018, 24, 1434-1444. [CrossRef]

114. Hartmaier, R.J.; Trabucco, S.E.; Priedigkeit, N.; Chung, J.H.; Parachoniak, C.A.; Vanden Borre, P.; Morley, S.; Rosenzweig, M.; Gay, L.M.; Goldberg, M.E.; et al. Recurrent hyperactive esr1 fusion proteins in endocrine therapy-resistant breast cancer. Ann. Oncol. 2018, 29, 872-880. [CrossRef] [PubMed]

115. Shibue, T.; Weinberg, R.A. Emt, cscs, and drug resistance: The mechanistic link and clinical implications. Nature reviews. Clin. Oncol. 2017, 14, 611-629.

116. Bernardo, G.M.; Lozada, K.L.; Miedler, J.D.; Harburg, G.; Hewitt, S.C.; Mosley, J.D.; Godwin, A.K.; Korach, K.S.; Visvader, J.E.; Kaestner, K.H.; et al. Foxa1 is an essential determinant of eralpha expression and mammary ductal morphogenesis. Development 2010, 137, 2045-2054. [CrossRef]

117. Hurtado, A.; Holmes, K.A.; Ross-Innes, C.S.; Schmidt, D.; Carroll, J.S. Foxa1 is a key determinant of estrogen receptor function and endocrine response. Nat. Genet. 2011, 43, 27-33. [CrossRef] [PubMed]

118. Manavathi, B.; Samanthapudi, V.S.; Gajulapalli, V.N. Estrogen receptor coregulators and pioneer factors: The orchestrators of mammary gland cell fate and development. Front. Cell Dev. Biol. 2014, 2, 34. [CrossRef]

119. Jozwik, K.M.; Carroll, J.S. Pioneer factors in hormone-dependent cancers. Nat. Rev. Cancer 2012, 12, 381-385. [CrossRef]

120. Magnani, L.; Patten, D.K.; Nguyen, V.T.; Hong, S.P.; Steel, J.H.; Patel, N.; Lombardo, Y.; Faronato, M.; Gomes, A.R.; Woodley, L.; et al. The pioneer factor pbx1 is a novel driver of metastatic progression in eralpha-positive breast cancer. Oncotarget 2015, 6, 21878-21891. [CrossRef] 
121. Magnani, L.; Ballantyne, E.B.; Zhang, X.; Lupien, M. Pbx1 genomic pioneer function drives eralpha signaling underlying progression in breast cancer. PLoS Genet. 2011, 7, e1002368. [CrossRef] [PubMed]

122. Razavi, P.; Chang, M.T.; Xu, G.; Bandlamudi, C.; Ross, D.S.; Vasan, N.; Cai, Y.; Bielski, C.M.; Donoghue, M.T.A.; Jonsson, P.; et al. The genomic landscape of endocrine-resistant advanced breast cancers. Cancer Cell 2018, 34, 427-438 e426. [CrossRef] [PubMed]

123. Ross-Innes, C.S.; Stark, R.; Teschendorff, A.E.; Holmes, K.A.; Ali, H.R.; Dunning, M.J.; Brown, G.D.; Gojis, O.; Ellis, I.O.; Green, A.R.; et al. Differential oestrogen receptor binding is associated with clinical outcome in breast cancer. Nature 2012, 481, 389-393. [CrossRef] [PubMed]

124. Wright, T.M.; Wardell, S.E.; Jasper, J.S.; Stice, J.P.; Safi, R.; Nelson, E.R.; McDonnell, D.P. Delineation of a foxa1/eralpha/agr2 regulatory loop that is dysregulated in endocrine therapy-resistant breast cancer. Mol. Cancer Res. 2014, 12, 1829-1839. [CrossRef] [PubMed]

125. Fu, X.; Jeselsohn, R.; Pereira, R.; Hollingsworth, E.F.; Creighton, C.J.; Li, F.; Shea, M.; Nardone, A.; De Angelis, C.; Heiser, L.M.; et al. Foxa1 overexpression mediates endocrine resistance by altering the er transcriptome and il-8 expression in er-positive breast cancer. Proc. Natl. Acad. Sci. USA 2016, 113, E6600-E6609. [CrossRef] [PubMed]

126. Leonard, M.; Zhang, X. Estrogen receptor coactivator mediator subunit 1 (med1) as a tissue-specific therapeutic target in breast cancer. J. Zhejiang Univ. Sci. B 2019, 20, 381-390. [CrossRef] [PubMed]

127. Zhang, X.; Krutchinsky, A.; Fukuda, A.; Chen, W.; Yamamura, S.; Chait, B.T.; Roeder, R.G. Med1/trap220 exists predominantly in a trap/mediator subpopulation enriched in rna polymerase ii and is required for er-mediated transcription. Mol. Cell 2005, 19, 89-100. [CrossRef] [PubMed]

128. Cui, J.; Germer, K.; Wu, T.; Wang, J.; Luo, J.; Wang, S.C.; Wang, Q.; Zhang, X. Cross-talk between her2 and med1 regulates tamoxifen resistance of human breast cancer cells. Cancer Res. 2012, 72, 5625-5634. [CrossRef]

129. Zhang, L.; Cui, J.; Leonard, M.; Nephew, K.; Li, Y.; Zhang, X. Silencing med1 sensitizes breast cancer cells to pure anti-estrogen fulvestrant in vitro and in vivo. PLoS ONE 2013, 8, e70641. [CrossRef]

130. Zhang, Y.; Leonard, M.; Shu, Y.; Yang, Y.; Shu, D.; Guo, P.; Zhang, X. Overcoming tamoxifen resistance of human breast cancer by targeted gene silencing using multifunctional prna nanoparticles. ACS Nano 2016, 11, 335-346. [CrossRef]

131. Anzick, S.L.; Kononen, J.; Walker, R.L.; Azorsa, D.O.; Tanner, M.M.; Guan, X.Y.; Sauter, G.; Kallioniemi, O.P.; Trent, J.M.; Meltzer, P.S. Alb1, a steroid receptor coactivator amplified in breast and ovarian cancer. Science 1997, 277, 965-968. [CrossRef] [PubMed]

132. Dihge, L.; Bendahl, P.O.; Grabau, D.; Isola, J.; Lovgren, K.; Ryden, L.; Ferno, M. Epidermal growth factor receptor (egfr) and the estrogen receptor modulator amplified in breast cancer (aib1) for predicting clinical outcome after adjuvant tamoxifen in breast cancer. Breast Cancer Res. Treat. 2008, 109, 255-262. [CrossRef] [PubMed]

133. Percharde, M.; Lavial, F.; Ng, J.H.; Kumar, V.; Tomaz, R.A.; Martin, N.; Yeo, J.C.; Gil, J.; Prabhakar, S.; $\mathrm{Ng}, \mathrm{H}$.H.; et al. Ncoa3 functions as an essential esrrb coactivator to sustain embryonic stem cell self-renewal and reprogramming. Genes Dev. 2012, 26, 2286-2298. [CrossRef] [PubMed]

134. Rohira, A.D.; Yan, F.; Wang, L.; Wang, J.; Zhou, S.; Lu, A.; Yu, Y.; Xu, J.; Lonard, D.M.; O'Malley, B.W. Targeting src coactivators blocks the tumor-initiating capacity of cancer stem-like cells. Cancer Res. 2017, 77, 4293-4304. [CrossRef] [PubMed]

135. Truong, T.H.; Hu, H.; Temiz, N.A.; Hagen, K.M.; Girard, B.J.; Brady, N.J.; Schwertfeger, K.L.; Lange, C.A.; Ostrander, J.H. Cancer stem cell phenotypes in er $(+)$ breast cancer models are promoted by pelp1/aib1 complexes. Mol. Cancer Res. 2018, 16, 707-719. [CrossRef] [PubMed]

136. Simoes, B.M.; Vivanco, M.D. Cancer stem cells in the human mammary gland and regulation of their differentiation by estrogen. Future Oncol. 2011, 7, 995-1006. [CrossRef]

137. Morimoto, K.; Kim, S.J.; Tanei, T.; Shimazu, K.; Tanji, Y.; Taguchi, T.; Tamaki, Y.; Terada, N.; Noguchi, S. Stem cell marker aldehyde dehydrogenase 1-positive breast cancers are characterized by negative estrogen receptor, positive human epidermal growth factor receptor type 2, and high ki67 expression. Cancer Sci. 2009, 100, 1062-1068. [CrossRef]

138. Harrison, H.; Simoes, B.M.; Rogerson, L.; Howell, S.J.; Landberg, G.; Clarke, R.B. Oestrogen increases the activity of oestrogen receptor negative breast cancer stem cells through paracrine egfr and notch signalling. Breast Cancer Res. 2013, 15, R21. [CrossRef] 
139. Tachi, K.; Shiraishi, A.; Bando, H.; Yamashita, T.; Tsuboi, I.; Kato, T.; Hara, H.; Ohneda, O. Foxa1 expression affects the proliferation activity of luminal breast cancer stem cell populations. Cancer Sci. 2016, 107, 281-289. [CrossRef]

140. Nasr, M.; Farghaly, M.; Elsaba, T.; El-Mokhtar, M.; Radwan, R.; Elsabahy, M.; Abdelkareem, A.; Fakhry, H.; Mousa, N. Resistance of primary breast cancer cells with enhanced pluripotency and stem cell activity to sex hormonal stimulation and suppression. Int. J. Biochem. Cell Biol. 2018, 105, 84-93. [CrossRef]

141. Yang, Y.; Leonard, M.; Zhang, Y.; Zhao, D.; Mahmoud, C.; Khan, S.; Wang, J.; Lower, E.E.; Zhang, X. Her2-driven breast tumorigenesis relies upon interactions of the estrogen receptor with coactivator med1. Cancer Res. 2018, 78, 422-435. [CrossRef] [PubMed]

142. de Leeuw, R.; Neefjes, J.; Michalides, R. A role for estrogen receptor phosphorylation in the resistance to tamoxifen. Int. J. Breast Cancer 2011, 2011, 232435. [CrossRef] [PubMed]

143. Vazquez-Martin, A.; Cufi, S.; Lopez-Bonet, E.; Corominas-Faja, B.; Cuyas, E.; Vellon, L.; Iglesias, J.M.; Leis, O.; Martin, A.G.; Menendez, J.A. Reprogramming of non-genomic estrogen signaling by the stemness factor sox2 enhances the tumor-initiating capacity of breast cancer cells. Cell Cycle 2013, 12, 3471-3477. [CrossRef] [PubMed]

144. Ma, R.; Karthik, G.M.; Lovrot, J.; Haglund, F.; Rosin, G.; Katchy, A.; Zhang, X.; Viberg, L.; Frisell, J.; Williams, C.; et al. Estrogen receptor beta as a therapeutic target in breast cancer stem cells. J. Natl. Cancer Inst. 2017, 109, 1-14. [CrossRef] [PubMed]

145. Lauricella, M.; Carlisi, D.; Giuliano, M.; Calvaruso, G.; Cernigliaro, C.; Vento, R.; D'Anneo, A. The analysis of estrogen receptor-alpha positive breast cancer stem-like cells unveils a high expression of the serpin proteinase inhibitor pi-9: Possible regulatory mechanisms. Int. J. Oncol. 2016, 49, 352-360. [CrossRef] [PubMed]

146. Wang, Z.; Zhang, X.; Shen, P.; Loggie, B.W.; Chang, Y.; Deuel, T.F. Identification, cloning, and expression of human estrogen receptor-alpha36, a novel variant of human estrogen receptor-alpha66. Biochem. Biophys. Res. Commun. 2005, 336, 1023-1027. [CrossRef] [PubMed]

147. Wang, Q.; Jiang, J.; Ying, G.; Xie, X.Q.; Zhang, X.; Xu, W.; Zhang, X.; Song, E.; Bu, H.; Ping, Y.F.; et al. Tamoxifen enhances stemness and promotes metastasis of eralpha36(+) breast cancer by upregulating aldh1a1 in cancer cells. Cell Res. 2018, 28, 336-358. [CrossRef] [PubMed]

148. Inoue, K.; Fry, E.A. Aberrant splicing of estrogen receptor, her2, and cd44 genes in breast cancer. Genet. Epigenet. 2015, 7, 19-32. [CrossRef]

149. Deng, H.; Zhang, X.T.; Wang, M.L.; Zheng, H.Y.; Liu, L.J.; Wang, Z.Y. Er-alpha36-mediated rapid estrogen signaling positively regulates er-positive breast cancer stem/progenitor cells. PLoS ONE 2014, 9, e88034.

150. Deng, H.; Yin, L.; Zhang, X.T.; Liu, L.J.; Wang, M.L.; Wang, Z.Y. Er-alpha variant er-alpha36 mediates antiestrogen resistance in er-positive breast cancer stem/progenitor cells. J. Steroid Biochem. Mol. Biol. 2014, 144 Pt B, 417-426. [CrossRef]

151. Knowlden, J.M.; Hutcheson, I.R.; Barrow, D.; Gee, J.M.; Nicholson, R.I. Insulin-like growth factor-i receptor signaling in tamoxifen-resistant breast cancer: A supporting role to the epidermal growth factor receptor. Endocrinology 2005, 146, 4609-4618. [CrossRef] [PubMed]

152. Knowlden, J.M.; Hutcheson, I.R.; Jones, H.E.; Madden, T.; Gee, J.M.; Harper, M.E.; Barrow, D.; Wakeling, A.E.; Nicholson, R.I. Elevated levels of epidermal growth factor receptor/c-erbb2 heterodimers mediate an autocrine growth regulatory pathway in tamoxifen-resistant mcf-7 cells. Endocrinology 2003, 144, 1032-1044. [CrossRef] [PubMed]

153. Santen, R.J.; Song, R.X.; Zhang, Z.; Kumar, R.; Jeng, M.H.; Masamura, A.; Lawrence, J., Jr.; Berstein, L.; Yue, W. Long-term estradiol deprivation in breast cancer cells up-regulates growth factor signaling and enhances estrogen sensitivity. Endocr. Relat. Cancer 2005, 12 (Suppl. 1), S61-S73. [CrossRef] [PubMed]

154. Nicholson, R.I.; Staka, C.; Boyns, F.; Hutcheson, I.R.; Gee, J.M. Growth factor-driven mechanisms associated with resistance to estrogen deprivation in breast cancer: New opportunities for therapy. Endocr. Relat. Cancer 2004, 11, 623-641. [CrossRef] [PubMed]

155. Zhou, W.; Slingerland, J.M. Links between oestrogen receptor activation and proteolysis: Relevance to hormone-regulated cancer therapy. Nat. Rev. Cancer 2014, 14, 26-38. [CrossRef] [PubMed]

156. Gradishar, W.J. Tamoxifen-What next? Oncologist 2004, 9, 378-384. [CrossRef] 
157. Garcia-Becerra, R.; Santos, N.; Diaz, L.; Camacho, J. Mechanisms of resistance to endocrine therapy in breast cancer: Focus on signaling pathways, mirnas and genetically based resistance. Int. J. Mol. Sci. 2012, 14, 108-145. [CrossRef]

158. Foley, J.; Nickerson, N.K.; Nam, S.; Allen, K.T.; Gilmore, J.L.; Nephew, K.P.; Riese, D.J., II. EGFR signaling in breast cancer: Bad to the bone. Semin. Cell Dev. Biol. 2010, 21, 951-960. [CrossRef]

159. Piasecka, D.; Braun, M.; Kitowska, K.; Mieczkowski, K.; Kordek, R.; Sadej, R.; Romanska, H. Fgfs/fgfrs-dependent signalling in regulation of steroid hormone receptors-Implications for therapy of luminal breast cancer. J. Exp. Clin. Cancer Res. 2019, 38, 230. [CrossRef]

160. Ali, S.; Coombes, R.C. Endocrine-responsive breast cancer and strategies for combating resistance. Nat. Rev. Cancer 2002, 2, 101-112. [CrossRef]

161. Hardt, O.; Wild, S.; Oerlecke, I.; Hofmann, K.; Luo, S.; Wiencek, Y.; Kantelhardt, E.; Vess, C.; Smith, G.P.; Schroth, G.P.; et al. Highly sensitive profiling of cd44+/cd24- breast cancer stem cells by combining global mrna amplification and next generation sequencing: Evidence for a hyperactive pi3k pathway. Cancer Lett. 2012, 325, 165-174. [CrossRef] [PubMed]

162. Pommier, S.J.; Hernandez, A.; Han, E.; Massimino, K.; Muller, P.; Diggs, B.; Chamberlain, E.; Murphy, J.; Hansen, J.; Naik, A.; et al. Fresh surgical specimens yield breast stem/progenitor cells and reveal their oncogenic abnormalities. Ann. Surg. Oncol. 2012, 19, 527-535. [CrossRef] [PubMed]

163. Donovan, C.A.; Pommier, R.F.; Schillace, R.; O’Neill, S.; Muller, P.; Alabran, J.L.; Hansen, J.E.; Murphy, J.A.; Naik, A.M.; Vetto, J.T.; et al. Correlation of breast cancer axillary lymph node metastases with stem cell mutations. JAMA Surg. 2013, 148, 873-878. [CrossRef] [PubMed]

164. Karthik, G.M.; Ma, R.; Lovrot, J.; Kis, L.L.; Lindh, C.; Blomquist, L.; Fredriksson, I.; Bergh, J.; Hartman, J. Mtor inhibitors counteract tamoxifen-induced activation of breast cancer stem cells. Cancer Lett. 2015, 367, 76-87. [CrossRef]

165. Vilquin, P.; Donini, C.F.; Villedieu, M.; Grisard, E.; Corbo, L.; Bachelot, T.; Vendrell, J.A.; Cohen, P.A. Microrna-125b upregulation confers aromatase inhibitor resistance and is a novel marker of poor prognosis in breast cancer. Breast Cancer Res. 2015, 17, 13. [CrossRef] [PubMed]

166. Asselin-Labat, M.L.; Shackleton, M.; Stingl, J.; Vaillant, F.; Forrest, N.C.; Eaves, C.J.; Visvader, J.E.; Lindeman, G.J. Steroid hormone receptor status of mouse mammary stem cells. J. Natl. Cancer Inst. 2006, 98, 1011-1014. [CrossRef]

167. Hebbard, L.; Steffen, A.; Zawadzki, V.; Fieber, C.; Howells, N.; Moll, J.; Ponta, H.; Hofmann, M.; Sleeman, J. Cd44 expression and regulation during mammary gland development and function. J. Cell Sci. 2000, $113 \mathrm{Pt}$ 14, 2619-2630.

168. Korkaya, H.; Paulson, A.; Iovino, F.; Wicha, M.S. Her2 regulates the mammary stem/progenitor cell population driving tumorigenesis and invasion. Oncogene 2008, 27, 6120-6130. [CrossRef]

169. Padua, M.B.; Bhat-Nakshatri, P.; Anjanappa, M.; Prasad, M.S.; Hao, Y.; Rao, X.; Liu, S.; Wan, J.; Liu, Y.; McElyea, K.; et al. Dependence receptor unc5a restricts luminal to basal breast cancer plasticity and metastasis. Breast Cancer Res. 2018, 20, 35. [CrossRef]

170. Choi, H.J.; Joo, H.S.; Won, H.Y.; Min, K.W.; Kim, H.Y.; Son, T.; Oh, Y.H.; Lee, J.Y.; Kong, G. Role of rbp2-induced er and igf1r-erbb signaling in tamoxifen resistance in breast cancer. J. Natl. Cancer Inst. 2018, 110. [CrossRef]

171. Acar, A.; Simoes, B.M.; Clarke, R.B.; Brennan, K. A role for notch signalling in breast cancer and endocrine resistance. Stem Cells Int. 2016, 2016, 2498764. [CrossRef] [PubMed]

172. Koch, U.; Lehal, R.; Radtke, F. Stem cells living with a notch. Development 2013, 140, 689-704. [CrossRef] [PubMed]

173. Raouf, A.; Zhao, Y.; To, K.; Stingl, J.; Delaney, A.; Barbara, M.; Iscove, N.; Jones, S.; McKinney, S.; Emerman, J.; et al. Transcriptome analysis of the normal human mammary cell commitment and differentiation process. Cell Stem Cell 2008, 3, 109-118. [CrossRef] [PubMed]

174. Yalcin-Ozuysal, O.; Fiche, M.; Guitierrez, M.; Wagner, K.U.; Raffoul, W.; Brisken, C. Antagonistic roles of notch and p63 in controlling mammary epithelial cell fates. Cell Death Differ. 2010, 17, 1600-1612. [CrossRef] [PubMed]

175. Yun, J.; Pannuti, A.; Espinoza, I.; Zhu, H.; Hicks, C.; Zhu, X.; Caskey, M.; Rizzo, P.; D'Souza, G.; Backus, K.; et al. Crosstalk between pkcalpha and notch-4 in endocrine-resistant breast cancer cells. Oncogenesis 2013, 2, e60. [CrossRef] [PubMed] 
176. Lombardo, Y.; Faronato, M.; Filipovic, A.; Vircillo, V.; Magnani, L.; Coombes, R.C. Nicastrin and notch4 drive endocrine therapy resistance and epithelial to mesenchymal transition in mcf7 breast cancer cells. Breast Cancer Res. 2014, 16, R62. [CrossRef] [PubMed]

177. Rizzo, P.; Miao, H.; D’Souza, G.; Osipo, C.; Song, L.L.; Yun, J.; Zhao, H.; Mascarenhas, J.; Wyatt, D.; Antico, G.; $\mathrm{t}$ al. Cross-talk between notch and the estrogen receptor in breast cancer suggests novel therapeutic approaches. Cancer Res. 2008, 68, 5226-5235. [CrossRef] [PubMed]

178. McClements, L.; Annett, S.; Yakkundi, A.; O’Rourke, M.; Valentine, A.; Moustafa, N.; Alqudah, A.; Simoes, B.M.; Furlong, F.; Short, A.; et al. Fkbpl and its peptide derivatives inhibit endocrine therapy resistant cancer stem cells and breast cancer metastasis by downregulating dll4 and notch4. BMC Cancer 2019, 19, 351. [CrossRef]

179. Haughian, J.M.; Pinto, M.P.; Harrell, J.C.; Bliesner, B.S.; Joensuu, K.M.; Dye, W.W.; Sartorius, C.A.; Tan, A.C.; Heikkila, P.; Perou, C.M.; et al. Maintenance of hormone responsiveness in luminal breast cancers by suppression of notch. Proc. Natl. Acad. Sci. USA 2012, 109, 2742-2747. [CrossRef]

180. Kahn, M. Can we safely target the wnt pathway? Nat. Rev. Drug Discov. 2014, 13, 513-532. [CrossRef]

181. Krausova, M.; Korinek, V. Wnt signaling in adult intestinal stem cells and cancer. Cell. Signal. 2014, 26, 570-579. [CrossRef] [PubMed]

182. Boman, B.M.; Fields, J.Z. An APC: WNT counter-current-like mechanism regulates cell division along the human colonic crypt axis: A mechanism that explains how apc mutations induce proliferative abnormalities that drive colon cancer development. Front. Oncol. 2013, 3, 244. [CrossRef] [PubMed]

183. Atlasi, Y.; Looijenga, L.; Fodde, R. Cancer stem cells, pluripotency, and cellular heterogeneity: A WNTer perspective. Curr. Top Dev. Biol. 2014, 107, 373-404. [PubMed]

184. Angeloni, V.; Tiberio, P.; Appierto, V.; Daidone, M.G. Implications of stemness-related signaling pathways in breast cancer response to therapy. Semin. Cancer Biol. 2015, 31, 43-51. [CrossRef] [PubMed]

185. Loh, Y.N.; Hedditch, E.L.; Baker, L.A.; Jary, E.; Ward, R.L.; Ford, C.E. The wnt signalling pathway is upregulated in an in vitro model of acquired tamoxifen resistant breast cancer. BMC Cancer 2013, 13, 174. [CrossRef] [PubMed]

186. Leung, E.Y.; Askarian-Amiri, M.E.; Sarkar, D.; Ferraro-Peyret, C.; Joseph, W.R.; Finlay, G.J.; Baguley, B.C. Endocrine therapy of estrogen receptor-positive breast cancer cells: Early differential effects on stem cell markers. Front. Oncol. 2017, 7, 184. [CrossRef]

187. Domenici, G.; Aurrekoetxea-Rodriguez, I.; Simoes, B.M.; Rabano, M.; Lee, S.Y.; Millan, J.S.; Comaills, V.; Oliemuller, E.; Lopez-Ruiz, J.A.; Zabalza, I.; et al. A sox2-sox9 signalling axis maintains human breast luminal progenitor and breast cancer stem cells. Oncogene 2019, 38, 3151-3169. [CrossRef] [PubMed]

188. Yu, Y.; Yin, W.; Yu, Z.H.; Zhou, Y.J.; Chi, J.R.; Ge, J.; Cao, X.C. Mir-190 enhances endocrine therapy sensitivity by regulating sox9 expression in breast cancer. J. Exp. Clin. Cancer Res. 2019, 38, 22. [CrossRef]

189. Petrova, R.; Joyner, A.L. Roles for hedgehog signaling in adult organ homeostasis and repair. Development 2014, 141, 3445-3457. [CrossRef]

190. Campbell, V.; Copland, M. Hedgehog signaling in cancer stem cells: A focus on hematological cancers. Stem Cells Cloning Adv. Appl. 2015, 8, 27-38.

191. Riobo-Del Galdo, N.A.; Lara Montero, A.; Wertheimer, E.V. Role of hedgehog signaling in breast cancer: Pathogenesis and therapeutics. Cells 2019, 8, 375. [CrossRef] [PubMed]

192. Ramaswamy, B.; Lu, Y.; Teng, K.Y.; Nuovo, G.; Li, X.; Shapiro, C.L.; Majumder, S. Hedgehog signaling is a novel therapeutic target in tamoxifen-resistant breast cancer aberrantly activated by pi3k/akt pathway. Cancer Res. 2012, 72, 5048-5059. [CrossRef] [PubMed]

193. Park, J.H.; Shin, J.E.; Park, H.W. The role of hippo pathway in cancer stem cell biology. Mol. Cells 2018, 41, 83-92. [PubMed]

194. Moroishi, T.; Hansen, C.G.; Guan, K.L. The emerging roles of yap and taz in cancer. Nat. Rev. Cancer 2015, 15, 73-79. [CrossRef] [PubMed]

195. Cordenonsi, M.; Zanconato, F.; Azzolin, L.; Forcato, M.; Rosato, A.; Frasson, C.; Inui, M.; Montagner, M.; Parenti, A.R.; Poletti, A.; et al. The hippo transducer taz confers cancer stem cell-related traits on breast cancer cells. Cell 2011, 147, 759-772. [CrossRef] [PubMed]

196. Zhao, B.; Li, L.; Guan, K.L. Hippo signaling at a glance. J. Cell Sci. 2010, 123, 4001-4006. [CrossRef] [PubMed] 
197. Berardi, D.E.; Raffo, D.; Todaro, L.B.; Simian, M. Laminin modulates the stem cell population in $\operatorname{lm} 05-\mathrm{e}$ murine breast cancer cells through the activation of the mapk/erk pathway. Cancer Res. Treat. Off. J. Korean Cancer Assoc. 2017, 49, 869-879. [CrossRef]

198. Sansone, P.; Savini, C.; Kurelac, I.; Chang, Q.; Amato, L.B.; Strillacci, A.; Stepanova, A.; Iommarini, L.; Mastroleo, C.; Daly, L.; et al. Packaging and transfer of mitochondrial DNA via exosomes regulate escape from dormancy in hormonal therapy-resistant breast cancer. Proc. Natl. Acad. Sci. USA 2017, 114, E9066-E9075. [CrossRef]

199. Sansone, P.; Berishaj, M.; Rajasekhar, V.K.; Ceccarelli, C.; Chang, Q.; Strillacci, A.; Savini, C.; Shapiro, L.; Bowman, R.L.; Mastroleo, C.; et al. Evolution of cancer stem-like cells in endocrine-resistant metastatic breast cancers is mediated by stromal microvesicles. Cancer Res. 2017, 77, 1927-1941. [CrossRef]

200. Castellaro, A.M.; Rodriguez-Baili, M.C.; Di Tada, C.E.; Gil, G.A. Tumor-associated macrophages induce endocrine therapy resistance in er+ breast cancer cells. Cancers 2019, 11, 189. [CrossRef]

201. Recouvreux, S.; Sampayo, R.; Bessone, M.I.; Simian, M. Microenvironment and endocrine resistance in breast cancer: Friend or foe? World J. Clin. Oncol. 2015, 6, 207-211. [CrossRef] [PubMed]

202. Callari, M.; Guffanti, A.; Solda, G.; Merlino, G.; Fina, E.; Brini, E.; Moles, A.; Cappelletti, V.; Daidone, M.G. In-depth characterization of breast cancer tumor-promoting cell transcriptome by rna sequencing and microarrays. Oncotarget 2016, 7, 976-994. [CrossRef] [PubMed]

203. Zlotnik, A.; Yoshie, O. The chemokine superfamily revisited. Immunity 2012, 36, 705-716. [CrossRef] [PubMed]

204. Charafe-Jauffret, E.; Ginestier, C.; Iovino, F.; Wicinski, J.; Cervera, N.; Finetti, P.; Hur, M.H.; Diebel, M.E.; Monville, F.; Dutcher, J.; et al. Breast cancer cell lines contain functional cancer stem cells with metastatic capacity and a distinct molecular signature. Cancer Res. 2009, 69, 1302-1313. [CrossRef] [PubMed]

205. Ginestier, C.; Liu, S.; Diebel, M.E.; Korkaya, H.; Luo, M.; Brown, M.; Wicinski, J.; Cabaud, O.; Charafe-Jauffret, E.; Birnbaum, D.; et al. Cxcr1 blockade selectively targets human breast cancer stem cells in vitro and in xenografts. J. Clin. Investig. 2010, 120, 485-497. [CrossRef] [PubMed]

206. Singh, J.K.; Farnie, G.; Bundred, N.J.; Simoes, B.M.; Shergill, A.; Landberg, G.; Howell, S.J.; Clarke, R.B. Targeting cxcr1/2 significantly reduces breast cancer stem cell activity and increases the efficacy of inhibiting her2 via her2-dependent and -independent mechanisms. Clin. Cancer Res. 2013, 19, 643-656. [CrossRef] [PubMed]

207. Kitajima, S.; Yoshida, A.; Kohno, S.; Li, F.; Suzuki, S.; Nagatani, N.; Nishimoto, Y.; Sasaki, N.; Muranaka, H.; Wan, Y.; et al. The rb-il-6 axis controls self-renewal and endocrine therapy resistance by fine-tuning mitochondrial activity. Oncogene 2017, 36, 5145-5157. [CrossRef] [PubMed]

208. Hu, H.; Sun, J.; Wang, C.; Bu, X.; Liu, X.; Mao, Y.; Wang, H. Il-33 facilitates endocrine resistance of breast cancer by inducing cancer stem cell properties. Biochem. Biophys. Res. Commun. 2017, 485, 643-650. [CrossRef]

209. Pichaud, F.; Walther, R.F.; Nunes de Almeida, F. Regulation of cdc42 and its effectors in epithelial morphogenesis. J. Cell Sci. 2019, 132, jcs217869. [CrossRef]

210. Bi, Y.; Tian, M.; Le, J.; Wang, L.; Liu, X.; Qu, J.; Hao, M. Study on the expression of pak4 and p54 protein in breast cancer. World J. Surg. Oncol. 2016, 14, 160. [CrossRef]

211. He, L.F.; Xu, H.W.; Chen, M.; Xian, Z.R.; Wen, X.F.; Chen, M.N.; Du, C.W.; Huang, W.H.; Wu, J.D.; Zhang, G.J. Activated-pak4 predicts worse prognosis in breast cancer and promotes tumorigenesis through activation of pi3k/akt signaling. Oncotarget 2017, 8, 17573-17585. [CrossRef] [PubMed]

212. Dart, A.E.; Box, G.M.; Court, W.; Gale, M.E.; Brown, J.P.; Pinder, S.E.; Eccles, S.A.; Wells, C.M. Pak4 promotes kinase-independent stabilization of rhou to modulate cell adhesion. J. Cell Biol. 2015, 211, 863-879. [CrossRef] [PubMed]

213. Zhuang, T.; Zhu, J.; Li, Z.; Lorent, J.; Zhao, C.; Dahlman-Wright, K.; Stromblad, S. P21-activated kinase group ii small compound inhibitor gne-2861 perturbs estrogen receptor alpha signaling and restores tamoxifen-sensitivity in breast cancer cells. Oncotarget 2015, 6, 43853-43868. [CrossRef] [PubMed]

214. Santiago-Gomez, A.; Kedward, T.; Simoes, B.M.; Dragoni, I.; NicAmhlaoibh, R.; Trivier, E.; Sabin, V.; Gee, J.M.; Sims, A.H.; Howell, S.J.; et al. Pak4 regulates stemness and progression in endocrine resistant er-positive metastatic breast cancer. Cancer Lett. 2019, 458, 66-75. [CrossRef] [PubMed]

215. Kim, J.H.; Yoon, S.Y.; Kim, C.N.; Joo, J.H.; Moon, S.K.; Choe, I.S.; Choe, Y.K.; Kim, J.W. The bmi-1 oncoprotein is overexpressed in human colorectal cancer and correlates with the reduced p16ink4a/p14arf proteins. Cancer Lett. 2004, 203, 217-224. [CrossRef] [PubMed] 
216. Guo, B.H.; Feng, Y.; Zhang, R.; Xu, L.H.; Li, M.Z.; Kung, H.F.; Song, L.B.; Zeng, M.S. Bmi-1 promotes invasion and metastasis, and its elevated expression is correlated with an advanced stage of breast cancer. Mol. Cancer 2011, 10, 10. [CrossRef] [PubMed]

217. Park, I.K.; Qian, D.; Kiel, M.; Becker, M.W.; Pihalja, M.; Weissman, I.L.; Morrison, S.J.; Clarke, M.F. Bmi-1 is required for maintenance of adult self-renewing haematopoietic stem cells. Nature 2003, 423, 302-305. [CrossRef] [PubMed]

218. Molofsky, A.V.; Pardal, R.; Iwashita, T.; Park, I.K.; Clarke, M.F.; Morrison, S.J. Bmi-1 dependence distinguishes neural stem cell self-renewal from progenitor proliferation. Nature 2003, 425, 962-967. [CrossRef] [PubMed]

219. Lukacs, R.U.; Memarzadeh, S.; Wu, H.; Witte, O.N. Bmi-1 is a crucial regulator of prostate stem cell self-renewal and malignant transformation. Cell Stem Cell 2010, 7, 682-693. [CrossRef]

220. Zacharek, S.J.; Fillmore, C.M.; Lau, A.N.; Gludish, D.W.; Chou, A.; Ho, J.W.; Zamponi, R.; Gazit, R.; Bock, C.; Jager, N.; et al. Lung stem cell self-renewal relies on bmi1-dependent control of expression at imprinted loci. Cell Stem Cell 2011, 9, 272-281. [CrossRef]

221. Siddique, H.R.; Saleem, M. Role of bmi1, a stem cell factor, in cancer recurrence and chemoresistance: Preclinical and clinical evidences. Stem Cells 2012, 30, 372-378. [CrossRef] [PubMed]

222. Kaufhold, S.; Garban, H.; Bonavida, B. Yin yang 1 is associated with cancer stem cell transcription factors (sox2, oct4, bmi1) and clinical implication. J. Exp. Clin. Cancer Res. 2016, 35, 84. [CrossRef]

223. Arif, K.; Hussain, I.; Rea, C.; El-Sheemy, M. The role of nanog expression in tamoxifen-resistant breast cancer cells. Onco Targets Ther. 2015, 8, 1327-1334. [PubMed]

224. Mehta, G.A.; Khanna, P.; Gatza, M.L. Emerging role of sox proteins in breast cancer development and maintenance. J. Mammary Gland Biol. Neoplasia 2019. [CrossRef] [PubMed]

225. Arnold, K.; Sarkar, A.; Yram, M.A.; Polo, J.M.; Bronson, R.; Sengupta, S.; Seandel, M.; Geijsen, N.; Hochedlinger, K. Sox2(+) adult stem and progenitor cells are important for tissue regeneration and survival of mice. Cell Stem Cell 2011, 9, 317-329. [CrossRef] [PubMed]

226. Weina, K.; Utikal, J. Sox 2 and cancer: Current research and its implications in the clinic. Clin. Transl. Med. 2014, 3, 19. [CrossRef]

227. Jeselsohn, R.; Cornwell, M.; Pun, M.; Buchwalter, G.; Nguyen, M.; Bango, C.; Huang, Y.; Kuang, Y.; Paweletz, C.; Fu, X.; et al. Embryonic transcription factor sox9 drives breast cancer endocrine resistance. Proc. Natl. Acad. Sci. USA 2017, 114, E4482-E4491. [CrossRef]

228. Xue, Y.; Lai, L.; Lian, W.; Tu, X.; Zhou, J.; Dong, P.; Su, D.; Wang, X.; Cao, X.; Chen, Y.; et al. Sox9/fxyd3/src axis is critical for er(+) breast cancer stem cell function. Mol. Cancer Res. 2019, 17, 238-249. [CrossRef]

229. Crambert, G.; Li, C.; Claeys, D.; Geering, K. Fxyd3 (mat-8), a new regulator of Na,K-Atpase. Mol. Biol. Cell 2005, 16, 2363-2371. [CrossRef]

230. Hiscox, S.; Barrett-Lee, P.; Borley, A.C.; Nicholson, R.I. Combining src inhibitors and aromatase inhibitors: A novel strategy for overcoming endocrine resistance and bone loss. Eur. J. Cancer 2010, 46, 2187-2195. [CrossRef]

231. Anbalagan, M.; Rowan, B.G. Estrogen receptor alpha phosphorylation and its functional impact in human breast cancer. Mol. Cell. Endocrinol. 2015, 418 Pt 3, 264-272. [CrossRef]

232. Piggott, L.; Silva, A.; Robinson, T.; Santiago-Gomez, A.; Simoes, B.M.; Becker, M.; Fichtner, I.; Andera, L.; Young, P.; Morris, C.; et al. Acquired resistance of er-positive breast cancer to endocrine treatment confers an adaptive sensitivity to trail through posttranslational downregulation of c-flip. Clin. Cancer Res. 2018, 24, 2452-2463. [CrossRef] [PubMed]

233. Xu, L.; Zhang, L.; Hu, C.; Liang, S.; Fei, X.; Yan, N.; Zhang, Y.; Zhang, F. Wnt pathway inhibitor pyrvinium pamoate inhibits the self-renewal and metastasis of breast cancer stem cells. Int. J. Oncol. 2016, 48, 1175-1186. [CrossRef] [PubMed]

234. Bertini, R.; Allegretti, M.; Bizzarri, C.; Moriconi, A.; Locati, M.; Zampella, G.; Cervellera, M.N.; Di Cioccio, V.; Cesta, M.C.; Galliera, E.; et al. Noncompetitive allosteric inhibitors of the inflammatory chemokine receptors cxcr1 and cxcr2: Prevention of reperfusion injury. Proc. Natl. Acad. Sci. USA 2004, 101, 11791-11796. [CrossRef] [PubMed]

235. Sun, Q.; Wang, Y.; Desgrosellier, J.S. Combined bcl-2/src inhibition synergize to deplete stem-like breast cancer cells. Cancer Lett. 2019, 457, 40-46. [CrossRef] [PubMed]

236. O'Brien, C.S.; Farnie, G.; Howell, S.J.; Clarke, R.B. Breast cancer stem cells and their role in resistance to endocrine therapy. Horm. Cancer 2011, 2, 91-103. [CrossRef] [PubMed] 
237. Shibata, M.; Hoque, M.O. Targeting cancer stem cells: A strategy for effective eradication of cancer. Cancers 2019, 11, 732. [CrossRef]

238. Saeg, F.; Anbalagan, M. Breast cancer stem cells and the challenges of eradication: A review of novel therapies. Stem Cell Investig. 2018, 5, 39. [CrossRef]

239. Dey, P.; Rathod, M.; De, A. Targeting stem cells in the realm of drug-resistant breast cancer. Breast Cancer 2019, 11, 115-135. [CrossRef]

240. Osipo, C.; Patel, P.; Rizzo, P.; Clementz, A.G.; Hao, L.; Golde, T.E.; Miele, L. Erbb-2 inhibition activates notch-1 and sensitizes breast cancer cells to a gamma-secretase inhibitor. Oncogene 2008, 27, 5019-5032. [CrossRef] [PubMed]

241. Ramakrishnan, G.; Davaakhuu, G.; Chung, W.C.; Zhu, H.; Rana, A.; Filipovic, A.; Green, A.R.; Atfi, A.; Pannuti, A.; Miele, L.; et al. Akt and 14-3-3 regulate notch4 nuclear localization. Sci. Rep. 2015, 5, 8782. [CrossRef] [PubMed]

242. Toska, E.; Osmanbeyoglu, H.U.; Castel, P.; Chan, C.; Hendrickson, R.C.; Elkabets, M.; Dickler, M.N.; Scaltriti, M.; Leslie, C.S.; Armstrong, S.A.; et al. Pi3k pathway regulates er-dependent transcription in breast cancer through the epigenetic regulator kmt2d. Science 2017, 355, 1324-1330. [CrossRef] [PubMed]

243. Bosch, A.; Li, Z.; Bergamaschi, A.; Ellis, H.; Toska, E.; Prat, A.; Tao, J.J.; Spratt, D.E.; Viola-Villegas, N.T.; Castel, P.; et al. Pi3k inhibition results in enhanced estrogen receptor function and dependence in hormone receptor-positive breast cancer. Sci. Transl. Med. 2015, 7, 283ra251. [CrossRef] [PubMed]

244. Carver, B.S.; Chapinski, C.; Wongvipat, J.; Hieronymus, H.; Chen, Y.; Chandarlapaty, S.; Arora, V.K.; Le, C.; Koutcher, J.; Scher, H.; et al. Reciprocal feedback regulation of pi3k and androgen receptor signaling in pten-deficient prostate cancer. Cancer Cell 2011, 19, 575-586. [CrossRef] [PubMed]

245. McGranahan, N.; Swanton, C. Clonal heterogeneity and tumor evolution: Past, present, and the future. Cell 2017, 168, 613-628. [CrossRef] [PubMed]

246. Gupta, R.G.; Somer, R.A. Intratumor heterogeneity: Novel approaches for resolving genomic architecture and clonal evolution. Mol. Cancer Res. 2017, 15, 1127-1137. [CrossRef] [PubMed]

247. Kreso, A.; O’Brien, C.A.; van Galen, P.; Gan, O.I.; Notta, F.; Brown, A.M.; Ng, K.; Ma, J.; Wienholds, E.; Dunant, C.; et al. Variable clonal repopulation dynamics influence chemotherapy response in colorectal cancer. Science 2013, 339, 543-548. [CrossRef] [PubMed]

248. Vitale, I.; Manic, G.; De Maria, R.; Kroemer, G.; Galluzzi, L. DNA damage in stem cells. Mol. Cell 2017, 66, 306-319. [CrossRef] [PubMed]

249. Taussig, D.C.; Miraki-Moud, F.; Anjos-Afonso, F.; Pearce, D.J.; Allen, K.; Ridler, C.; Lillington, D.; Oakervee, H.; Cavenagh, J.; Agrawal, S.G.; et al. Anti-cd38 antibody-mediated clearance of human repopulating cells masks the heterogeneity of leukemia-initiating cells. Blood 2008, 112, 568-575. [CrossRef]

250. Zhang, W.C.; Shyh-Chang, N.; Yang, H.; Rai, A.; Umashankar, S.; Ma, S.; Soh, B.S.; Sun, L.L.; Tai, B.C.; Nga, M.E.; et al. Glycine decarboxylase activity drives non-small cell lung cancer tumor-initiating cells and tumorigenesis. Cell 2012, 148, 259-272. [CrossRef]

251. Beier, D.; Hau, P.; Proescholdt, M.; Lohmeier, A.; Wischhusen, J.; Oefner, P.J.; Aigner, L.; Brawanski, A.; Bogdahn, U.; Beier, C.P. Cd133(+) and cd133(-) glioblastoma-derived cancer stem cells show differential growth characteristics and molecular profiles. Cancer Res. 2007, 67, 4010-4015. [CrossRef]

252. Pastushenko, I.; Blanpain, C. Emt transition states during tumor progression and metastasis. Trends Cell Biol. 2019, 29, 212-226. [CrossRef] [PubMed]

253. Latil, M.; Nassar, D.; Beck, B.; Boumahdi, S.; Wang, L.; Brisebarre, A.; Dubois, C.; Nkusi, E.; Lenglez, S.; Checinska, A.; et al. Cell-type-specific chromatin states differentially prime squamous cell carcinoma tumor-initiating cells for epithelial to mesenchymal transition. Cell Stem Cell 2017, 20, 191-204. [CrossRef] [PubMed]

254. Pastushenko, I.; Brisebarre, A.; Sifrim, A.; Fioramonti, M.; Revenco, T.; Boumahdi, S.; Van Keymeulen, A.; Brown, D.; Moers, V.; Lemaire, S.; et al. Identification of the tumour transition states occurring during emt. Nature 2018, 556, 463-468. [CrossRef]

255. Ruscetti, M.; Quach, B.; Dadashian, E.L.; Mulholland, D.J.; Wu, H. Tracking and functional characterization of epithelial-mesenchymal transition and mesenchymal tumor cells during prostate cancer metastasis. Cancer Res. 2015, 75, 2749-2759. [CrossRef] 
256. Xu, L.; Mao, X.; Guo, T.; Chan, P.Y.; Shaw, G.; Hines, J.; Stankiewicz, E.; Wang, Y.; Oliver, R.T.D.; Ahmad, A.S.; et al. The novel association of circulating tumor cells and circulating megakaryocytes with prostate cancer prognosis. Clin. Cancer Res. 2017, 23, 5112-5122. [CrossRef]

257. Yu, M.; Bardia, A.; Wittner, B.S.; Stott, S.L.; Smas, M.E.; Ting, D.T.; Isakoff, S.J.; Ciciliano, J.C.; Wells, M.N.; Shah, A.M.; et al. Circulating breast tumor cells exhibit dynamic changes in epithelial and mesenchymal composition. Science 2013, 339, 580-584. [CrossRef] [PubMed]

258. Papadaki, M.A.; Stoupis, G.; Theodoropoulos, P.A.; Mavroudis, D.; Georgoulias, V.; Agelaki, S. Circulating tumor cells with stemness and epithelial-to-mesenchymal transition features are chemoresistant and predictive of poor outcome in metastatic breast cancer. Mol. Cancer Ther. 2019, 18, 437-447. [CrossRef] [PubMed]

259. Yamashita, N.; Tokunaga, E.; Iimori, M.; Inoue, Y.; Tanaka, K.; Kitao, H.; Saeki, H.; Oki, E.; Maehara, Y. Epithelial paradox: Clinical significance of coexpression of e-cadherin and vimentin with regard to invasion and metastasis of breast cancer. Clin. Breast Cancer 2018, 18, e1003-e1009. [CrossRef]

260. Rybak, A.P.; He, L.; Kapoor, A.; Cutz, J.C.; Tang, D. Characterization of sphere-propagating cells with stem-like properties from du145 prostate cancer cells. Biochim. Biophys. Acta 2011, 1813, 683-694. [CrossRef] [PubMed]

261. Batlle, E.; Clevers, H. Cancer stem cells revisited. Nat. Med. 2017, 23, 1124-1134. [CrossRef] [PubMed]

262. Greten, F.R. Cancer: Tumour stem-cell surprises. Nature 2017, 543, 626-627. [CrossRef] [PubMed]

263. de Sousa e Melo, F.; Kurtova, A.V.; Harnoss, J.M.; Kljavin, N.; Hoeck, J.D.; Hung, J.; Anderson, J.E.; Storm, E.E.; Modrusan, Z.; Koeppen, H.; et al. A distinct role for lgr5(+) stem cells in primary and metastatic colon cancer. Nature 2017, 543, 676-680. [CrossRef] [PubMed]

264. Weigelt, B.; Peterse, J.L.; van't Veer, L.J. Breast cancer metastasis: Markers and models. Nat. Rev. Cancer 2005, 5, 591-602. [CrossRef] [PubMed]

265. Gupta, G.P.; Massague, J. Cancer metastasis: Building a framework. Cell 2006, 127, 679-695. [CrossRef] [PubMed]

266. De Craene, B.; Berx, G. Regulatory networks defining emt during cancer initiation and progression. Nat. Rev. Cancer 2013, 13, 97-110. [CrossRef] [PubMed]

267. Tsai, J.H.; Yang, J. Epithelial-mesenchymal plasticity in carcinoma metastasis. Genes Dev. 2013, 27, $2192-2206$. [CrossRef] [PubMed]

268. Yao, D.; Dai, C.; Peng, S. Mechanism of the mesenchymal-epithelial transition and its relationship with metastatic tumor formation. Mol. Cancer Res. 2011, 9, 1608-1620. [CrossRef]

269. Gunasinghe, N.P.; Wells, A.; Thompson, E.W.; Hugo, H.J. Mesenchymal-epithelial transition (met) as a mechanism for metastatic colonisation in breast cancer. Cancer Metastasis Rev. 2012, 31, 469-478. [CrossRef] 